\title{
MEDICAL MALPRACTICE AND \\ MANAGED CARE ORGANIZATIONS: THE IMPLIED WARRANTY OF QUALITY
}

\author{
WILLIAM S. BREWBAKER III* \\ I \\ INTRODUCTION
}

With the advent of managed health care, medical malpractice law is once again seizing the public's attention. The prime targets in the new malpractice litigation are often not only doctors, but also the corporations that pay them. Generically referred to as managed care organizations ("M CO s"), these entities include health maintenance organizations ("HMOs"), preferred provider organizations ("PPOs") and other vertically and horizontally integrated provider networks. MCOs are unlike traditional indemnity insurers in that they sell prepaid medical services rather than financial coverage, limit their members' choice of providers, make independent medical determinations about what care is worth paying for, employ payment mechanisms that induce providers to economize on treatment, or engage in some combination of the above. A s M CO s have become more aggressive in their cost-containment efforts, public apprehension about market-based medical care has increased. When medical errors occur, members of managed care plans are inclined to blame not only the doctor but the MCO as well.

Blaming an M CO for deficient medical care is one thing; getting a judgment against it is another. Courts currently employ general principles of vicarious liability in deciding whether an M CO can be held accountable for a physician's malpractice. Under these rules, an MCO's liability is dependent upon proof of either the MCO's direct negligence or the existence of an actual or apparent master-servant (that is, control) relationship between the MCO and the physician. B ecause there is a strong presumption in A merican law that physicians are independent contractors, MCOs that do not employ their physicians often

Copyright (C) 1997 by L aw and Contemporary Problems.

* A ssociate Professor of Law, U niversity of A labama.

I am grateful to Ken A braham, Charles G amble, Mark H all, Susan H amill, Clark Havighurst, W ythe Holt, D avid Hyman, K en K ress, Tom M etzloff, Susan R andall, and Norman Stein for helpful comments on earlier drafts of this article. I also benefited from comments made during presentations of this paper at the IM PA CS Conference sponsored by Duke L aw School and the R obert W ood J ohnson Foundation, and at a faculty workshop at the U niversity of A labama School of Law. A ny errors are, of course, my own. I am indebted to D ean Ken Randall and the William H. Sadler Fund of the U niversity of A labama Law School Foundation for generous research support. H eather Boren, A llison M ays, Tom M onk, and O mari W inbush provided excellent research assistance. Special thanks are due to $\mathrm{W}$ anda $\mathrm{E}$ lliot for her tireless secretarial assistance. 
enjoy virtual immunity from liability for provider mal practice. ${ }^{1}$

A s MCOs have come to exert more influence in the provision of medical services, their lack of accountability for provider negligence has become untenable. It has been challenged as a matter of fairness (many M CO practices seem likely to contribute to medical injury), as a matter of safety (MCOs are in a good position to take positive steps to prevent medical injuries), and as a matter of efficient compensation for injury (MCOs are already in the insurance business and are good risk-spreaders). There is also palpable judicial unease over the state of the law; courts appear to be pushing vicarious liability principles to the limit in order to generate appropriate levels of accountability. The Clinton proposal to reform the nation's health care system initially included provisions that would have made MCOs solely liable for their physicians' malpractice. ${ }^{2}$ In addition, several states either have recently enacted or are considering legislation that would expand M CO liability for physicians' negligence as well as for benefit determination decisions. ${ }^{3}$

I will argue that courts should impose a tort-based implied warranty of quality on MCOs (defined as firms that are in the business of selling, or arranging for the sale of, medical services). U nder the warranty, M CO s would be liable for selling physician services that are negligently rendered, that is, for their physicians' malpractice. Grounding M CO malpractice liability in a tortbased implied warranty theory will no doubt strike many readers as a novel extension of tort law; this article's primary contribution is to explain that this seemingly novel theory is in fact strongly rooted in, and consistent with, established common law principles. The positive legal argument I will make is supported along the way by the normative arguments in favor of M CO liability already noted, as well as by additional policy considerations.

The argument begins with the observation that caveat emptor has never

1. MCOs do not typically enjoy de jure immunity from malpractice liability. In a few states, HMO s enjoy de jure immunity conferred by statute or based on the "corporate practice of medicine" doctrine. For a discussion of these immunities, see William S. B rewbaker III, M anaged Care Liability, in HEALTH CARE CORPORATE LA W: MANAGED CARE, 6-1, 6-30 to 6-32 (Mark A. Hall \& William S. Brewbaker III eds., 1996).

2. See K enneth S. A braham \& Paul C. Weiler, Enterprise M edical L iability and the Evolution of the A merican Health Care System, 108 HARV. L. REV. 381, 382-84 (1994) [hereinafter Enterprise $M$ edical L iability] (describing the demise of enterprise liability provisions in the Clinton Plan); Sharon $M$. G lenn, Comment, Tort L iability of I ntegrated H ealth Care D elivery Systems: B eyond $E$ nterprise $L \mathrm{i}$ ability, 29 W A KE F OREST L. REV. 305, 309-11 (1994) (same).

3. L egislation recently enacted in Texas and M issouri would end immunities currently enjoyed by HMOs. Texas courts had previously recognized a "corporate practice of medicine" defense to HMO liability claims. See, e.g., W illiams v. Good H ealth Plus, 743 S.W.2d 373, 378 (T ex. A pp. 1988). U nder the new legislation, HM Os can be liable for failure "to exercise ordinary care when making health care treatment decisions" and "for harm to an ... enrollee proximately caused by the health care treatment decisions made by its (1) employees, (2) agents, (3) ostensible agents, or (4) representatives who are acting on its behalf and over whom it has the right to exercise influence or control or has actually exercised influence or control which result in the failure to exercise ordinary care." TEX. CIV. PRAC. \& REM. CODE ANN. § 88.002 (West 1997). A recently enacted M issouri statute removes immunity previously conferred on HMO s pursuant to that state's HMO A ct. See H.R. 335, 89th Gen. A ssembly (M o. 1997) (enacted J une 25, 1997). O ther states are considering similar legislation. See Leigh Page, Texas E yes M easure to Extend L iability to M anaged Care, A M. M ED. N EWS, A pr. 14, 1997, at 4. 
governed the sale of professional or trade services. At least since Blackstone wrote, most professionals and other service providers were held to an implied contractual undertaking to render their services with "integrity, diligence, and skill." ${ }^{4}$ Significantly, when medical services were being sold, the physicianseller's obligation to the patient (as embodied in the law of medical malpractice) strongly resembled the implicit contractual undertakings the law imposed on other professionals. Nevertheless, the physician's obligation originated in tort rather than contract, reflecting judicial solicitude for the patient's interest in bodily integrity. In other words, for the last 200-plus years, sellers of medical services have owed their patients a tort-based implied warranty of quality. ${ }^{5}$ A s I frame the issue of MCO liability, the question is simple: Should the implied warranty that already governs physician-sellers of medical services also apply to MCOs? I will argue from both a positive and a normative perspective that it should.

The argument might end there, were it not for a well-known line of cases commonly understood to hold that products liability principles do not apply to the sellers of services, including medical services. ${ }^{6}$ Though developed in an entirely different context, the principles of products liability law bear a sufficient resemblance to the implied warranty of quality proposed here that it is necessary to distinguish this line of cases (which I shall refer to as "products versus services" cases). A n historical examination of the gradual evolution of products liability law will reveal that the "products versus services" cases are not opposed to the implied warranty. R ather, they are best understood as judicial rejections of plaintiffs' attempts to replace the negligence standard of malprac-

4. 3 WILLIAM B LACKSTONE, COMMENTARIES ON THE LA WS OF ENGLAND 163 (1825).

5. See infra Part II.

6. See Restatement (ThIRD) OF THe LAW OF TORTS: PROductSLIABILITY § 19(b) (Proposed Final D raft 1997) ("Services, even when provided commercially, are not products."); id. cmt. $f$ ("Courts are unanimous in refusing to categorize commercially provided services as products for the purposes of strict products liability in tort."); see, e.g., Stewart Warner Corp. v. B urns Int'| Security Serv., I nc., 343 F. Supp 953 (N.D. III. 1972) (security services); Pepsi Cola Bottling Co. v. Superior Burner Serv. Co., 427 P.2d 833 (A laska 1967) (repair services); Lucas v. H amm, 364 P.2d 685 (Cal. 1961) (legal services); A llied Properties v. J ohn Blume \& A ssocs., 102 Cal. R ptr. 259 (Cal. Ct. A pp. 1972) (engineering services); Micciche v. Eastern Elevator Co., 645 A .2d 278 (Pa. Super. Ct. 1994) (elevator maintenance); Hannis v. A shland State Gen. Hosp., 544 A .2d 574 (Pa. Commw. Ct. 1989) (medical services); H oven v. K elble, 256 N.W.2d 379 (Wis. 1977) (medical services). But see J ohnson v. Sears, R oebuck \& Co., 355 F. Supp. 1065 (E.D. W is. 1973) (allowing strict product liability action against hospital for mechanical and administrative services); B royles v. Brown E ngineering Co., 151 So.2d 767 (A la. 1963) (engineering services). Courts are divided in their treatment of so-called "hybrid" sales/services transactions. The most recent R estatement divides such transactions into two categories: "[i]n the first, the product component is consumed in the course of providing the service, as when a hair dye is used in treating a customer's hair in a salon. . . . [T] ]he transaction is ordinarily treated as a sale of the material." RESTATEMENT, supra, $\S 20 \mathrm{cmt}$. d. The second category involves cases where "the product component ... is not consumed or permanently transferred to the customeras when defective scissors are used in the hair salon." Id. Such transactions "ordinarily [are] treated as ... not involving the sale of the product to the customer." Id. Compare N ewmark v. G imbel's, I nc., 258 A .2d 697 (N.J . 1969) (holding a beauty parlor liable for injuries caused by chemicals applied to patron's hair) with Coleman v. Charlesworth, 608 N.E.2d 464 (III. A pp. Ct. 1992) (holding that balloon ride is a service). A ccording to the R estatement, a "strong majority" of jurisdictions hold that hospitals are not sellers "of the products they supply in connection with the provision of medical care, regardless of the circumstances." RESTA TEM ENT, supra, $\S 20 \mathrm{cmt} d$. 
tice liability with a more demanding liability standard modeled after section $402 \mathrm{~A}$ of the R estatement (Second) of Torts. U nlike the strict liability standard rejected in the "products versus services" cases, the implied warranty advocated here would not raise the legal benchmark used to measure the quality of medical services.

A fter concluding that the "products versus services" cases do not preclude the implied warranty as a matter of positive law, I argue that products liability precedents actually provide support for it. In addition to the strict liability principle rejected in the "products versus services" cases, products liability law also includes cases embodying what will be referred to as the "seller accountability" principle. In addition to tracing the origins of the implied warranty to the traditional malpractice obligations of physicians and distinguishing the "products versus services" cases, Part II of this article invokes the seller accountability theme to support the imposition of an implied warranty against MCOs. Part III provides a complementary policy analysis, focusing on traditional concerns about fairness, efficiency, compensation, and deterrence as well as on the suitability of the implied warranty doctrine to resolution of M CO liability claims. Part IV outlines the contours of the implied warranty in greater detail and makes specific suggestions for applying implied warranty doctrine in liability litigation against MCOs. The article concludes with a brief reflection on the usefulness of implied warranties for resolving pressing issues in managed care liability litigation.

This article focuses on the implied warranty of quality as a mechanism for dealing with an important, though relatively narrow, problem: M CO s' liability for the negligent acts and omissions of affiliated providers. H owever, the warranty might well produce other even more significant benefits were it to become the starting point in medical liability litigation. Specifically, it provides a potential avenue for bringing E R ISA preemption jurisprudence in line with the realities of managed care. ERISA has been held to preempt actions against employer-sponsored health plans, including M COs, where the action is a "claim for benefits" or alleges direct negligence on the part of the MCO, but not where the lawsuit is based on vicarious liability for physician negligence. ${ }^{7}$ The ERISA cases thus assume a bright-line division of responsibility between health plans and providers for the care patients receive- physicians "treat" and plans "pay."

O ne of the themes of this article will be that this conception of medical

7. In the leading case on this point, the Fifth Circuit acknowledged that utilization reviewers make medical determinations much in the way attending physicians do. See Corcoran v. United Health Care, 965 F.2d 1321 (5th Cir. 1992). H owever, the court held that because those determinations are made in order to decide whether an ERISA plan member is entitled to benefits, the plaintiff's negligence claim amounted to an allegation that "a tort [was] committed in the course of handling a benefit determination." Id. at 1332. A s such, the claim would be preempted under ERISA. See Tolton v. A merican Biodyne, I nc., 48 F.3d 937 (6th Cir. 1995); K uhl v. L incoln N at'l H ealth Plan, 999 F.2d 298 (8th Cir. 1993), cert. denied, 114 S.Ct. 694 (1994); Spain v. A etna Life Ins. Co., 11 F.3d 129 (9th Cir. 1993); Pomeroy v. J ohns Hopkins Medical Servs., 868 F.Supp. 110 (D. M d. 1994); Stroker v. Rubin, 1994 WL 719694 (E.D. Pa. Dec. 22, 1994); see also Pilot Life v. Dedeaux, 481 U.S. 41 (1987) (holding that ERISA preempts state tort claim alleging bad faith breach of ERISA plan contract). 
practice is untenable in the context of managed care. In managed care, the provision of medical services is a joint effort of health plan and provider; MCOs inevitably exert significant influence over the shape of the care their members receive. ${ }^{8}$ W hile an examination of the interplay between ERISA preemption jurisprudence and the implied warranty is beyond the scope of this article, it is worth noting briefly that an MCO's decision to withhold benefits (scrutiny of which is currently preempted) would constitute a breach of the implied warranty of quality if the result of the decision were that the treatment the patient received fell below the standard of care. Given the origins of the implied warranty in the traditional law of medical malpractice, ${ }^{9}$ and the refusal of courts to invoke ERISA to preempt medical malpractice claims, ${ }^{10}$ the implied warranty may well survive an ERISA preemption challenge, even when the plaintiff's case could be recharacterized as a "claim for benefits" that would have been preempted under current E RISA standards.

\section{MEdical MaLPRACTICE LAW THROUGH a WARRANTY LENS}

\section{A. M alpractice $L$ aw and $H$ ealth Care D elivery}

A t least since Blackstone's time, courts have imposed what amounts to a tort-based implied warranty of quality on sellers of medical services. ${ }^{11}$ The common law required "every one who undertakes any office, employment, trust, or duty ... to perform it with integrity, diligence, and skill." ${ }^{12}$ Like other service providers, physicians could be held liable for "neglect or unskillful management." ${ }^{13}$ However, in contrast to the obligations of lawyers, tailors, innkeepers and others, the physician's duty of care arose not primarily from implied contractual obligations but rather from the patient's interest in bodily integrity. The Commentaries described "mala praxis" as a "great misdemeanor and offense at common law" ${ }^{14}$ and classified it with other "injuries which affect the personal security of individuals," ${ }^{15}$ including threats, assaults, battery, mayhem and defamation. The implied warranty of quality as embodied in physi-

8. See infra Part II.C.

9. See infra Part II.A.

10. A Ithough a few lower courts have held that ERISA preempts malpractice claims against MCOs in connection with service provided through an ERISA plan, see, e.g., Pomeroy v. Johns Hopkins M ed. Services, Inc., 868 F. Supp 110 (D. M d. 1994), there appears to be a trend emerging among the U.S. Circuit Courts of A ppeal to the contrary. See, e.g., Pacificare of Oklahoma, Inc. v. Burrage, 59 F.3d 151 (10th Cir. 1995); R ice v. Panchal, 65 F.3d 637 (7th Cir. 1995); D ukes v. U .S. H ealthcare, Inc., 57 F.3d 350 (3d Cir. 1995). A ssuming this trend continues, the implied warranty of quality advocated in this article should withstand a claim of ERISA preemption.

11. See Michael M. G reenfield, Consumer Protection in Service Transactions-I mplied Warranties and Strict L iability in Tort, 1974 U TA H L. R EV . 661, 663-68 \& nn. 20-29 (characterizing negligence as a form of implied warranty and collecting cases).

12. BLACKSTONE, supra note 4 , at 163.

13. Id. at 122 .

14. Id.

15. Id. at 119 . 
cians' malpractice obligations has thus traditionally been a hybrid of tort obligations and implied contractual undertaking.

B oth the contract and tort aspects of the malpractice warranty strongly suggest that it should apply to MCOs. First, as a contractual warranty, it is implied as an incident to the sale of services. A s sellers, physicians have long been obligated to stand behind their services and are subject to liability for services performed without due diligence and skill. MCOs likewise have the contractual obligation to deliver value in exchange for their patrons' money. Second, because the implied warranty of quality is grounded in tort law's special solicitude for bodily integrity, courts should be hesitant to allow MCOs to avoid its reach. Like physicians, MCOs trade in medical services, the skillful and diligent delivery of which is crucial to patients' personal bodily security. This suggests not only that courts should be skeptical of contractual attempts to evade the warranty, ${ }^{16}$ but also that they should be slow to absolve M CO-sellers of responsibility for the quality of the services they sell.

If physicians' obligations under the law of medical malpractice can be aptly characterized as an implied warranty that ought to attach to any seller of medical services, one might well ask why courts have not yet seized on this theory to impose liability on $\mathrm{MCO}^{17}{ }^{17}$ The most important reason implied warranty theories have not taken hold is probably that, until recently, only physicians sold medical services.

In this respect, the evolution of the medical profession has been different from that of other occupations. Other service providers-for example, butchers, tailors, and mechanics-were absorbed into corporate structures long before physicians began to be. While corporations sold the goods and services these workers produced, physicians continued to practice solo or in small groups. $^{18}$ This was partly the result of policies implemented by organized medi-

16. Courts generally refuse to enforce waivers of malpractice liability. See, e.g. Tunkl v. R egents of the U niversity of California, 383 P.2d 441 (Cal. 1963) (holding that release executed by indigent patient in consideration of free medical care held unenforceable); E mory U niv. v. Porubianski, 282 S.E.2d 903 ( $G$ a. 1981) (holding that release executed in consideration of low-cost care held unenforceable). See also RESTA TEMENT (THIRD) OF TORTS, supra note 6, § 14 ("Disclaimers and limitations of remedies by product sellers or other distributors, waivers by product purchasers, and other similar contractual exculpations, oral or written, do not bar or reduce otherwise valid products liability claims against sellers or other distributors of new products for harm to persons.") Notwithstanding the tort origins of the implied warranty, courts would be justified in permitting reasonable contractual modifications in appropriate cases. Cf. id. cmt. d ("[Section 14] does not address whether consumers, especially when represented by informed and economically powerful consumer groups or intermediaries, with full information and sufficient bargaining power, may contract with product sellers to accept curtailment of liability for concomitant benefits.... W Wen such contracts are accompanied by alternative nontort remedies that serve as an adequate quid pro quo for reducing or eliminating rights to recover in tort, arguments may support giving effect to such agreements. Such contractual arrangements raise policy questions different from those raised by this Section and require careful considerations by the courts.") See also Clark C. HavighuRst, HeAlth Care ChOICES: Private Contracts as INSTRUMENTS OF HEALTH REFORM 265-302 (1995) (arguing that some consumers might rationally prefer to alter otherwise applicable malpractice rules and suggesting possible modifications).

17. In fact, the outcomes of MCO liability cases are often more consistent with an implied warranty theory than with the legal theories that courts purport to apply. See infra Part IV B.

18. See paul Starr, The Social Transformation of American Medicine 25 (1982); 2 The American LAW Institute, Reporter's Study: EnTERPRISE Responsibility For 
cine that were aimed at preserving physicians' control over the conditions of their work, ${ }^{19}$ and partly the result of the fact that there were no appreciable economies of scale in medical practice. ${ }^{20}$

The ability of physicians to resist corporate control for the better part of this century allowed the law of medical malpractice to remain fundamentally unchanged-even as industrial developments sparked a revolution in other legal frameworks. For example, as buyers in commercial transactions increasingly began dealing directly with distant manufacturers, courts began imposing implied warranties that protected them against economic loss. ${ }^{21}$ Later, concerns over the accountability of distant sellers to consumers led to the strict products liability regime embodied in section 402A of the Restatement (Second) of Torts. Doctors, however, were already subject to the tort-based implied warranty embodied in the sale of medical services. A s long as medical care continued to be sold on a person-to-person basis, ${ }^{22}$ there was no need to

PER SONA L I NJURY 115 (Paul C. Weiler ed., 1991) (describing the A merican medical system as "one of the last outposts of the independent entrepreneur").

19. See STARR, supra note 18, at 229-31 (noting five structural changes affecting the distribution of power in A merican medicine: (1) the growth of specialization, which "encouraged former rivals to put aside their differences and work together in behalf of ... common political objectives," (2) the professions securing control over medical licensing and therefore of labor markets for medical services; (3) the avoidance of "commercialism" in medicine, which allowed physicians freely to avail themselves of capital supplied by others; (4) the "elimination of countervailing power" in medical care by prohibitions on participation by the state, corporations, or voluntary associations in the market for medical services; and (5) "the establishment of specific spheres of professional authority," which prevented functional integration that might have challenged professional prerogatives.) See also Mark A. Hall, Institutional Control of Physician Behavior: L egal Barriers to $\mathrm{H}$ ealth Care Cost Containment, $137 \mathrm{U}$. PA . L. R EV . 431, 434 (1988) (arguing that "cost containment programs are fundamentally at odds with the professional libertarian values of physician autonomy that are embedded in the law to preserve the practitioner's independence from the institution"); Clark C. H avighurst, Professional R estraints on Innovation in Health Care Financing, 1978 DUKE L.J. 303 (cataloguing mechanisms whereby organized medicine restrained financing innovations that threatened physician interests).

20. See STA R R, supra note 18, at 19, 26-27, 206, 217, 218, 220.

21. See generally K.N. L lewellyn, Of Warranty of Q uality, and Society: II, 37 Co L U M. L. RE V. 341, 349-53 (1937).

22. For the better part of this century, it would have been highly implausible to characterize most hospitals as "sellers" of medical services provided by staff physicians. Even when medical services were provided in the hospital, physicians' success in shielding themselves from any accountability to hospital administrators led to a "physician's workshop" or "aircraft carrier" model of hospital administration, remnants of which still persist. This model presupposes a fine line between "medical services," for which physicians are responsible and the hospital is not, and "administrative services," for which the reverse is true. 1 BARRY R. FURROW ET AL., HEALTH LAW, 449 (1995); see also A lbain v. Flower Hosp., 553 N.E.2d 1038, 1046 (O hio 1990) (explaining that a physician's negligence does not automatically impose liability on a hospital). The model affirmatively avoids any integrating of physicians' services with those of the hospital. See J effrey $\mathrm{H}$ arris, The Internal O rganization of H ospitals: Some E conomic Implications, 8 B ELL J. E CON. 467, 470-72 (1977) (describing organizational model of hospital as "two firms loosely connected by a complex set of nonmarket relations"). It also ensured physician supremacy, since under a regime of cost-based reimbursement and indemnity insurance, physicians could use their patients' purchasing power as leverage against the hospital. Indeed, prior to the demise of hospitals' charitable immunity, physician control within the hospital even led courts to impose liability on physicians for nurses' (i.e., hospital employees') torts in some circumstances. See 1 FURROW ET A L., supra, § 7-2(b) (1995) (describing the "Captain of the Ship" and "borrowed servant" doctrines). See also Truhitte v. French H osp., 180 Cal. R ptr. 152, 160 (Cal. Ct. A pp. 1982) (tracing the origin of the Captain of the Ship doctrine to "the need to assure plaintiffs a source of recovery for 
discard the tort-based "malpractice" vocabulary of medical liability.

A $n$ additional reason courts have not used implied warranty theory to analyze medical liability claims against MCOs is the association of "implied warranty" terminology with the law of products liability. A s mentioned earlier, a well-known line of cases is commonly understood to hold that products liability principles do not apply to the sellers of services, including medical services. Because the implied warranty of quality proposed here traces its origins to the traditional obligations of sellers of medical services embodied in malpractice law and not to principles of products liability, these cases are arguably irrelevant. E ven so, there is a strong association in the legal mind between implied warranties and principles of products liability generally. The next section argues that, properly understood, the "products versus services" cases did not reject implied warranty as a theory of M CO liability, but were merely a repudiation of proposals to replace the negligence-based standard of malpractice law with more demanding liability standards modeled after section 402A of the R estatement (Second) of Torts.

\section{B. The O rigin of the "Products V ersus Services" D istinction}

While it is easy to find judicial statements to the effect that products liability principles do not apply to the sale of services, ${ }^{23}$ those statements are ultimately misleading. Products liability is a complex agglomeration of tort and contracts doctrines, including strict liability, negligence, vicarious liability, and express and implied warranty. A s a result, it is easy to paint with too broad a brush in describing products liability rules. ${ }^{24}$ This section reviews gradual developments in products liability law and product markets and contrasts them with the comparatively stable (until recently) world of medical practice and medical liability. In so doing, it argues that the "products versus services" cases have been largely misunderstood. Those cases clearly did turn away attempts

malpractice at a time when many hospitals enjoyed charitable immunity"). A lthough the importance of the Captain of the Ship doctrine has diminished with the abrogation of charitable immunity and the expansion of hospital liability generally, see Stephen H. Price, The Sinking of the "Captain of the Ship": Reexamining the Vicarious L iability of an O perating Surgeon for the N egligence of A ssisting Hospital Personnel, 10 J. LEG. MED. 323 (1989), the doctrine can be seen as an expression of "seller accountability" occurring outside the confines of products liability law. See infra Part II.C. (discussing principle of seller accountability). The analogy is particularly apt given the de facto control physicians have exercised over hospitals for most of this century. See generally STA RR, supra note 28, at 162-169; R obert C. Clark, D oes the N onprofit Form Fit the H ospital Industry?, 93 H A R V. L. R E V. 1416 (1980); M ark V. Pauly \& M ichael R edisch, The N ot-for-Profit H ospital as a Physicians'Cooperative, $63 \mathrm{~A} \mathrm{M}$. E coN. REV. 87 (1973). Hospital administrators today enjoy considerably more power over physicians than was previously the case. INSTITUTE OF MEDICINE, FOR-PROFIT ENTERPRISE IN HEALTH CARE 172 (1986) (cataloguing reasons for increased power). N ot surprisingly, as hospitals have (correctly) come to be viewed as more involved in the delivery of "medical" services, their liability has increased. See generally 1 FURROW ET AL., $\S \S 7-2$ to 7-4 (1995) (describing evolution of tort obligations of hospitals).

23. See supra note 6 .

24. The most common example of this tendency is the frequent association of products liability law with strict liability, which, in fact, applies only to manufacturing defects but not to design defects or failures to warn. 
to use products liability precedent to displace the negligence-based malpractice standard. They need not, however, be read as forbidding the application of products liability concepts to consumer transactions with $\mathrm{MCO}$ s or as requiring that caveat emptor become the governing principle in M CO-consumer relationships. Such readings completely ignore an important principle of products liability law-that commercial sellers incur tort-based obligations to protect the public from personal injury.

A s already noted, common law courts during B lackstone's era did not hesitate to employ tort and implied contract principles to require physicians and other sellers of services to render those services with diligence and skill. By contrast, probably because a purchaser could inspect goods before paying for them, caveat emptor initially governed the sale of products. ${ }^{25}$ The law implied a warranty that the seller had title to the goods he sold, but held the seller accountable with respect to the quality of the goods only in a few exceptional cases-where the seller had given an express warranty, where the goods were "provisions" (in which case they had to be "wholesome"), or where the seller knowingly misrepresented the goods or attempted to hide their defects. ${ }^{26}$

N eedless to say, caveat emptor did not survive. By the mid-nineteenth century, courts had begun implying warranties of merchantability in connection with the sale of goods. However, these warranties protected buyers only against intangible economic loss. ${ }^{27}$ Purchasers suffering personal injury or destruction of property could recover only in tort. F urthermore, under the rule of Winterbottom v. Wright, ${ }^{28}$ manufacturers of defective products could be sued in tort only by a direct purchaser. Unless a plaintiff could show that his direct seller were at fault (either as manufacturer or by failing to inspect the product adequately), he had no remedy for personal injury.

Winterbottom eventually went the way of caveat emptor. Support for the Winterbottom holding had been gradually eroding ${ }^{29}$ for some time when the case of $\mathrm{M}$ acPherson $\mathrm{v}$. B uick M otor $\mathrm{C} 0 .^{30}$ was decided. In M acPherson, Judge Cardozo held that

[i]f the nature of a thing is such that it is reasonably certain to place life and limb at

25. See Jones v. J ust, L.R. 3 Q.B. 197 (1868); 3 BLACKSTONE, supra note 4, at 165; J on Chait, Note, Continuing the Common $\mathrm{L}$ aw R esponse to the $\mathrm{N}$ ew Industrial State: The Extension of E nterprise L iability to Consumer Services, 22 U CLA L. REV . 401, 404-07 (1974).

26. 3 B LA CKSTONE, supra note 4, at 164-65; KEETON ET. AL., PROSSER AND KEETON ON TORTS $\S$ $95 \mathrm{~A}$, at 679 (5th ed. 1984).

27. SeeKEETON ET AL., supra note 26 , § 95 A , at 680-81.

28. 152 Eng. Rep. 402 (1842).

29. The most important exception to the Winterbottom rule dealt with inherently dangerous products. KEETON ET. A L., supra note 26 , $\$ 96$, at 682 . Other exceptions included negligence in connection with a sale, when the conduct of the vendor was "imminently dangerous," H uset v. J. I. Case Threshing Co., 120 F. 865, 870 (8th Cir. 1903), and injury to a non-party to a contract when the injury resulted from an "invitation" issued by the defendant, id. at 870-71. See also, B ohlen, L iability of M anufacturers to Persons O ther than Their I mmediate Vendees, 45 L.Q . R E V. 343, 361-62 (1929). ("[M acP herson] has had a pronounced effect in stimulating the already existing tendency to extend the previously recognized exceptions... [s]o widely ... that in many A merican jurisdictions little or nothing is left of the immunity.").

30. 111 N.E. 1050 (N.Y. 1916). 
peril when negligently made, ... [and] there is added knowledge that the thing will be used by persons other than the purchaser and used without new tests, then, irrespective of contract, the manufacturer of this thing of danger is under a duty to make it carefully. ${ }^{31}$

The manufacturer's duty extended beyond its direct purchaser (the retailer to whom it sold the defective product) to any foreseeable user. ${ }^{32}$

A Ithough $\mathrm{M}$ acPherson is now regarded by many tort scholars as a revolutionary opinion, ${ }^{33}$ it had no contemporaneous consequences for medical malpractice law. Judge Cardozo's holding that the prospect of personal injury gave rise to tort duties on the part of manufacturers irrespective of contractual privity created no new obligations for sellers of medical services, as they were almost always sold and provided by the same person. A nd, as explained earlier, common law judges had used tort principles to require physicians to provide services with diligence and skill at least as far back as B lackstone's time.

O nly with the next products liability revolution, which gave birth to strict liability and culminated in the adoption of section 402A, did developments in products liability law threaten to alter the medical malpractice landscape. $\mathrm{M}$ acP herson had left injured consumers, assuming they could prove negligence, with potential remedies against both manufacturers and sellers. However, some consumers were injured by defective products notwithstanding nonnegligent manufacture or inspection in the distribution chain. Courts began permitting implied warranty theories to support recovery for personal injuries caused by product defects irrespective of negligence. ${ }^{34}$ Then, in $\mathrm{H}$ enningsen $\mathrm{v}$. Bloomfield Motors, Inc., ${ }^{35}$ an implied warranty of quality was applied against a manufacturer that was not in privity of contract with the injured party. ${ }^{36}$ Even so, because the implied warranty theories were derived from contract princi-

31. Id. at 1053.

32. See RESTATEMENT (THIRD) OF TORTS, supra note $6, \S 1$ ("O ne engaged in the business of selling or otherwise distributing products who sells or distributes a defective product is subject to liability for harm to persons or property caused by the defect."); William L. Prosser, The Fall of the Citadel (Strict L iability to the Consumer), 50 M INN. L. REV. 791, 817-20 (1966) ("A ny user or consumer of the product ... is protected by the strict liability rule.") (collecting cases).

33. See KEETON ET AL., supra note $26, \S 96$ at 683 ("[The opinion's] reasoning and fundamental philosophy were clearly that the manufacturer, by placing the car upon the market, assumed a responsibility to the consumer, resting not upon the contract but upon the relation arising from his purchase, together with the foreseeability of harm if proper care were not used."); B ohlen, supra note 29, at 36162 (noting decision's effect in "stimulating the ... . tendency to extend the . . . exceptions"); but see George L. Priest, The Invention of Enterprise L iability: A Critical History of the Intellectual Foundations of Modern Tort Law, 14 J. LEGAL STUD. 461, 468 (1985) (noting limited implications of $\mathrm{M}$ acP herson).

34. See generally KEETON ET A L., supra note 26 , § 97 , at $690-91$. This development began with cases involving food, see R yan v. Progressive G rocery Stores, 175 N.E. 105 (N.Y . 1931) (Cardozo, J.); M azetti v. A rmour \& Co., 135 P. 633 (Wash. 1913), but was gradually extended to other products, see, e.g., B.F. Goodrich Co. v. H ammond, 269 F.2d 501 (10th Cir. 1959); Spence v. Three R ivers Builders \& M asonry Supply, Inc., 90 N.W .2d 873 (M ich. 1958); Continental Copper \& Steel Indus. v. "R ed" Cornelius, 104 So.2d 40 (Fla. Dist. Ct. A pp. 1958).

35. 161 A.2d 69 (N.J . 1960).

36. See Prosser, supra note 46 , at 791 ("In the field of products liability, the date of the fall of the citadel of privity can be fixed with some certainty. It was May 9, 1960, when the Supreme Court of $\mathrm{N}$ ew J ersey announced the decision in Henningsen ...." ). 
ples, many of the old contractual defenses resurfaced to bar recovery. ${ }^{37}$ Subsequent opinions-and ultimately section 402A of the R estatement-relied on the prospect of personal injury and property damage to relocate strict products liability in tort. ${ }^{38}$ The result was "a discrete area of tort law that borrows from both negligence and warranty." "As the most recent R estatement explains, modern products liability law "merges the concept of implied warranty, in which negligence is not required, with the concept of negligence in tort, in which contractual privity is not required." ${ }^{40}$ The final result has been the preservation of consumer remedies not only against the manufacturer of a defective product, but also against commercial sellers at all levels of the distribution chain. ${ }^{41}$

In contrast with the $\mathrm{M}$ acP herson decision, which had no immediate implications for medical malpractice law, section 402A of the R estatement threatened a revolution. By the 1970 s, commentators ${ }^{42}-$ and even an occasional judge ${ }^{43}-$ were advocating that service providers be held strictly liable for "defects." Professor Michael Greenfield's much cited 1974 article proposed defining a "defective" medical service as any misdiagnosis if diagnosis were possible given the state of the art, any failure to select the best course of treatment, or any misapplication of the treatment selected. ${ }^{44}$ While hybrid sales/service transactions continue to vex the courts, ${ }^{45}$ judges have been virtually unanimous in rejecting the strict liability standard as applied to pure service transactions. ${ }^{46}$ The reasons typically given include a reluctance to make the service provider (especially the physician) a guarantor of results when "[m]edical and many other professional services tend often to be experimental in nature, dependent

37. See KEETON ET AL., supra note 26 , § 97, at 690-91. A mong the defenses invoked by defendants to resist the warranty rationale for products liability were plaintiff's lack of reliance on the warranty, e.g., D avis v. Williams, 198 S.E. 357 (G a. 1938); K roger v. Lewelling, 145 So. 726 (M iss. 1933), privity, see Swift \& C 0. v. W ells, 110 S.E .2d 203 (V a. 1959); D ecker and Sons v. Capps, 164 S.W .2d 828 (Tex. 1942), notice, see B onker v. Ingersoll Products Corp., 132 F.Supp. 5 (D. M ass. 1955); Whitfield v. J essup, 193 P.2d 1 (Cal. 1948), and disclaimer, see Traylor E ngineering \& M anufacturing Co. v. National Container Corp., 70 A .2d 9 (Del. Super. Ct. 1949); Valley Refrigeration Co. v. Lange Co., 8 N.W. 2d 294 (W is. 1943); R ockwood \& Co. v. Parrot \& Co., 19 P.2d 423 (O r. 1933). See generally William L. Prosser, The A ssault U pon the Citadel: Strict Liability to the Consumer, 69 Y A LE L. J. 1098, 1123-1131 (1960).

38. The leading case is Greenman v. Yuba Power Products, 377 P.2d 897 (Cal. 1963); RESTA TEMENT (SE COND) OF THE LA W OF TORTS § 402A, cmt. m (1965) ("The liability stated in this Section does not rest upon negligence. It is strict liability .... The basis of liability is purely one of tort.").

39. RESTATEMENT (THIRD) OF TORTS, supra note 6 , $\S 1 \mathrm{cmt}$. a.

40. Seeid.

41. See id. § 20; see also infra Part II.

42. See C hait, supra note $25 ; \mathrm{G}$ reenfield, supra note 11.

43. See, e.g., J ohnson v. Sears, R oebuck \& Co., 355 F. Supp. 1065 (E.D. W is. 1973) (allowing strict liability action against hospital for mechanical and administrative services); B royles $\mathrm{V}$. B rown Engineering Co., 151 So.2d 767 (A la. 1963) (allowing strict liability against a civil engineer for faulty surveying work).

44. See Greenfield, supra note 11 (summarized in Hoven v. K elble, 256 N.W .2d 379, 386-87 (W is. 1977)).

45. See RESTATEMENT (THIRD) OF TORTS, supra note 6 , $\S 20 \mathrm{cmt}$. d, ('No unifying test had been devised to determine whether strict liability applies in any given sales-service combination.").

46. See generally supra note 6 . 
on factors beyond the control of the professional, and devoid of certainty or assurance of results." ${ }^{47}$ In addition, there was concern that strict liability would raise the price of medical services, with the result that they would be harder to obtain. ${ }^{48}$

$\mathrm{H}$ ad the courts accepted the invitation to apply section $402 \mathrm{~A}$ to medical services, judicial treatment of MCO liability for physician malpractice would have been markedly different. Instead of relying on principles of vicarious liability to determine M CO liability, the courts, following products liability principles, would have first inquired as to whether the services were defectiveperhaps using the standard suggested by Professor G reenfield. The next step would have been to ask whether the M CO was a "commercial seller" of the defective services. $^{49}$ In the case of an HMO or any other organization that sold prepaid medical care rather than merely financial services, that question would be answered in the affirmative, and the M CO and provider would be jointly liable for the defect. ${ }^{50}$ The trier-of-fact court would not have inquired as to whether the provider was the MCO's employee or an independent contractor. Indeed, principles of vicarious liability would have been entirely irrelevant.

Of course, as noted above, the courts have overwhelmingly rejected the application of strict products liability to services, including medical services. ${ }^{51}$ These cases, however, did not consider whether corporate sellers of medical services should be held liable for malpractice, that is, the physician's negligence). Indeed, all one can infer from the cases distinguishing between products and services is that they have decisively rejected strict liability as a benchmark. ${ }^{52}$ This is significant because, as stated above, this article's thesis is that

47. H oven v. Kelble, 256 N.W .2d 379, 391 (W is. 1977); see also H off v. Zimmer, I nc., 746 F. Supp. 872,876 (W.D. Wis. 1990); B royles v. B rown Engineering Co., 151 So.2d 767, 771 (A la. 1963); G agne v. Bertram, 275 P.2d 15, 21 (Cal. 1954); Newmark v. G imbel's, Inc., 258 A .2d 697, 702-03 (N .J . 1969); Baptista v. Saint B arnabas M edical Center, 262 A .2d 902, 907 (N .J. Super. Ct. A pp. D iv. 1970).

48. See, e.g., H oven, 256 N.W .2d at 391; H eld v. 7-E leven Ford Store, 438 N.Y .S. 2d 976, 978 (Sup. Ct. 1981) (considering cost of all types of services); Heirs of Fruge v. Blood Services, $365 \mathrm{~F}$. Supp. 1344, 1350 (W.D. La. 1973); Shepard v. A lexian Brothers Hospital, I nc. 109 Cal. R ptr. 132, 136 (Cal. Ct. A pp. 1973); Dibblee v. Dr. W. H. G roves Latter-D ay Saints H osp., 364 P.2d 1085, 1087 (U tah 1961); cf., LaR ossa v. Scientific Design, Inc., 402 F.2d 937, 942 (3d Cir. 1968) (arguing that services involve "no mass production of goods or a large body of distant consumers whom it would be unfair to require to trace the article they used along the channels of trade to the original manufacturer and there to pinpoint an act of negligence remote from their knowledge and even from their ability to inquire"). But see infra Part II.C. (noting M CO influence over shaping of medical services and arguing that plaintiff's ability to recover should not depend on ability to pinpoint responsibility on either M CO or provider). See also G reenfield, supra note 11, at 683 (“[A ] surprisingly large number [of courts] seem content to state the obvious: a sale of services is not a sale of goods. From this, the courts jump to the conclusion that there is no warranty and no strict liability."). Cf. RESTA TEMENT (THIRD) OF TORTS, supra note 6 , $\S 20$ note d (arguing that public policy supports hospital immunity from strict liability on the basis of holding to the effect the need for access to medical services outweighs the need for strict liability).

49. SeeRESTATEMENT (THIRD) OF TORTS, supra note 6, § 1, cmt a.

50. See id; see also infra Part IV.

51. See generally supra note 6 .

52. See, e.g., H oven, 256 N.W. $2 d$ at 387 ("adoption of the plaintiff's theory of liability ... would set the standard of performance for the entire medical profession at the zenith of that profession's achievement, a level at which by definition virtually no one could perform all the time"); id at 390-93 (listing arguments for and against strict liability); RESTA TEMENT (THIRD) OF TORTS, supra note 6 , § 
products liability principles support the proposition that $\mathrm{MCOS}$, as corporate sellers of medical services, impliedly warrant the quality of the services they sell. The law of medical malpractice, of course, provides an obvious fault-based (that is, non-strict liability) benchmark for quality.

On reflection, it is easy to see why parties to health care litigation have rarely, if ever, argued for the imposition of an implied warranty of quality apart from claims of strict liability. A s explained above, caveat emptor has not been a feature of malpractice law (or of the law of services in general) at least since the time of Blackstone. There was thus no need for the nineteenth-century courts that implied warranties of merchantability in connection with the sale of products to employ them in service transactions. The negligence-based law of medical malpractice was, in effect, an implied warranty of quality that predated the industrial era. Nor was there a need for a decision like MacPherson $\mathrm{v}$. Buick Motor $\mathrm{Co}^{53}$ to expand the universe of potential defendants in malpractice cases. U ntil recently, there was no distribution chain in health care; the patient bought medical services from the physician who rendered them. A s a result, privity and analogous tort concepts posed no obstacle to recovery.

E ven in the 1960s and 1970s, when section 402A seemed to make strict liability for medical services a possibility, privity was not a problem to plaintiffs. $^{54}$ D efendants in such cases were physicians and hospitals, and each was al-

20 note $d$ (arguing that hospital immunity comports with public policy because "the nature of the [medical] services, the utility of, and the need for them, involving as they do the health and even survival of many people, are so important to the general welfare as to outweigh in the policy scale any need for the imposition on dentists and doctors of the rules of strict liability in tort") (citing N ewmark v. Gimbel's, I nc., 258 A .2d 697, 703 (N.J . 1969)). The academic debate likewise focused on the merits of strict liability. Compare Chait, supra note 25 and Greenfield, supra note 11, with R ichard A. E pstein, M edical Malpractice: The Case for Contract, 1 A M. B A R F OU ND. RES. J . 87 (1976). Courts have occasionally articulated policy concerns linked more closely to "seller accountability" in the course of deciding "hybrid" cases. In some of these cases, these policies are used to justify imposing strict liability on the hospital as a seller. See, e.g., G rubb v. A Ibert E instein M ed. Ctr., 387 A .2d 480 (Pa. Super. Ct. 1978). Cases noting "seller accountability" principles but rejecting strict liability refer to the absence of a distribution chain in the service setting. See, e.g., L aR ossa v. Scientific D esign Co., 402 F.2d 937, 942 (3d Cir. 1968) ("Professional services do not ordinarily lend themselves to the doctrine of tort liability without fault because they lack the elements which give rise to the doctrine. There is no mass production of goods or a large body of distant consumers whom it would be unfair to require to trace the article they used along the channels of trade to the original manufacturer and there to pinpoint an act of negligence remote from their knowledge and even from their ability to inquire."). Once M COs become involved in the provision of health care, however, a distribution chain is created. See infra Part II.C. (applying seller accountability principles to MCOs); infra Part IV (describing operating MCOS).

53. 111 N.E. 1050 (N.Y. 1916)

54. The "seller accountability" principles discussed in Part II.C. could conceivably have been applied in the 1960s and 1970s so as to permit recovery against hospitals for physician negligence. This would have been a substantially larger expansion of liability than the one proposed in this article, however, for two reasons: (1) H ospitals did not sell physician services; with the exception of some hospitalbased physicians, doctors enjoyed complete financial independence from the hospitals at which they practiced; see J ames F. B lumstein \& Frank A. Sloan, A ntitrust and Hospital Peer Review, 51 LA W \& CONTEMP. PROBS. 7, 16-17 (Spring 1988); (2) Hospitals exercised relatively little control over staff physicians, see $\mathrm{H}$ all, supra note 19 , at 525-32. While it would be difficult to characterize a hospital as a seller of physician services in most cases even today, a hospital might well assume such liability by virtue of its participation in a physician-hospital organization ( $\mathrm{PHO}$ ) or other MCO. Implied warranty 
ready accountable to injured consumers. Strict liability merely promised to make recovery against these defendants easier by reducing the plaintiff's burden of proof. By the 1970s, a few H M O s had been formed, but these early ventures were primarily clinics whose physicians were full-time employees. ${ }^{55}$ A gain, because of the actual employment relationship, corporate liability was not an issue. MCO liability has become a concern only in recent years as MCOs with relatively loose provider relationships have intervened in physician-patient relationships and taken a more aggressive hand in "managing care."

O ne might have expected that the recent advent of complex distribution systems for medical services would have led courts and litigants to imply warranties of quality against M CO s in short order. A gain, however, because of the absence of any distribution chain in the sale of medical services and because of cases that seemed to hold that "products liability law" only applies to "products" and not to "services," this has not yet been the case. I argue below that both existing legal principles and policy considerations support holding MCOs to an implied warranty of quality.

\section{The Principle of Seller A ccountability}

Properly understood, products liability law actually provides affirmative support for the implication of a warranty of quality against M CO s. The implied warranty of quality involves nothing more (or less) than the application to MCOs of conventional principles of commercial seller accountability for personal injury, with the physician's negligence-rather than strict liabilityserving as the benchmark against which the quality of medical services is measured. U nder these conventional rules of accountability, M CO s should be liable if they sell "defective" services (that is, services that do not conform to the malpractice standard of care), regardless of whether the plaintiff can show that the M CO itself has acted unreasonably.

The seller accountability strand of products liability law deals primarily with the question of which parties will be held responsible for personal injuries arising out of product defects. A s explained earlier, under the rule of Winterbottom v. Wright, ${ }^{56}$ a plaintiff could not recover for product injuries in tort unless in privity of contract with the tortfeasor. In M cP herson v. Buick M otor D ivision $\mathrm{C}_{0 .}{ }^{57} \mathrm{~J}$ udge Cardozo rescinded this rule, permitting injured plaintiffs to recover from manufacturers that were "upstream" in the distribution chain. With the advent of strict liability, seller accountability principles were also in-

theory might also be applied to hold hospitals liable for torts of hospital-based physicians, such as emergency-room staff.

55. See Clark C. Havighurst, HMOs and the Market for Health Services, 35 LAW \& CONTEMP. PROBS. 716, 718-20 (A utumn 1970) (describing early H M O s); N ote, The Role of Prepaid G roup Practice in Relieving the M edical Care Crisis, 84 H A R V. L. R EV. 887, 901-921 (1971) (same).

56. 152 E ng. R ep. 402 (1842).

57. 111 N.E. 1050 (N.Y. 1916). 
voked to permit recovery against non-negligent "downstream" parties, such as nonmanufacturing retailers. ${ }^{58}$ Under current rules, any seller of a defective product is liable for product defects.

The seller accountability cases that present the clearest analogy to MCO relationships with affiliated providers are those holding a manufacturer liable for defective components made by others but included in the manufacturerdefendant's product. M CO s sell a single package of health coverage that combines the traditionally separate elements of health care finance and delivery. ${ }^{59}$ Medical services are the primary "components" incorporated into the M CO's product. In some cases, an M CO's network will include a full range of institutional and professional providers; in others, it will include some lesser subset, such as primary care or specialist services. ${ }^{60}$

Courts routinely hold manufacturers liable for defects in components incorporated into the manufacturer's product, even when the defect can be traced to the maker of the component. Liability is supported by a number of considerations. First, "the assembler is in the best position to evaluate the safety of the use of a component part in its final product and can exert power over component manufacturers to ensure the safety of parts." ${ }^{61}$ Second, "the manufacturerassembler's act of putting its name on a product and placing it in the stream of commerce induces the public to purchase and use the product with the belief that the product, as a whole, is safe and fit for its ordinary applications." ${ }^{62}$ Third, rather than permit difficulties of proof to prevent product-injury victims from recovery, "it is more just to place the burden on the various parties of the distributional chain to 'fight out the question of responsibility among themselves, ${ }^{\prime \prime}{ }^{64}$ with the expectation that the parties can negotiate efficient insurance and indemnity arrangements. ${ }^{65}$

Each of these policies is easily applied to MCOs. Like the manufacturer that includes components made by others in the product it sells, M CO s are in a

58. The leading case was Vandermark v. Ford M otor Co., 391 P.2d 168, 171-72 (Cal. 1964) (en banc), which was followed in RESTATEMENT (SECOND) OF TORTS, supra note 38, $\S 402 A$, cmt. f.; RESTA TEMENT (THIRD) OF TORTS, supra note 6 , § 1.

59. See Part IV infra.

60. See J onathon Weiner $\&$ Gregory de Lissovoy, Razing a Tower of Babel: A Taxonomy for Managed Care and Health Insurance Plans, $18 \mathrm{~J}$. HEALTH POL. POL'Y \& L. 75 (1993); MANAGED CARE, supra note $1, \S 1.4 .1$ (describing various organizational models of $\mathrm{HMOS}$ ), $\S 2.2$ (describing organizational structure of PPOs), § 4.2 (describing organizational structure of direct contracting networks and company clinics), § 5.12 (describing structure physician-hospital organizations), § 5.13 (describing structure of foundation-model MCOS).

61. I AMERICAN LAW OF PRODUCTS LIABILITY § 8:1 (3rd ed. 1987) (citing Kealoha V. E. I. DuPont De Nemours and Co., 844 F. Supp. 590 (D. Haw. 1994), aff'd, 82 F.3d 894 (9th Cir. 1996), Exxon Shipping Co. v. Pacific R esources, Inc., 789 F.Supp. 1521 (D .H aw. 1991).

62. Id. (citing M orris v. A merican M otors C orp., 459 A .2d 968 (V t. 1982)).

63. Cf. Saieva v. Budget Rent-a-Car, 591 N.E.2d 507 (III. A pp. Ct. 1992) (holding that plaintiff could not recover for product defect where he could not prove product was in defective condition when manufacturer sold it to retailer and retailer enjoyed statutory immunity from strict liability for manufacturing defects).

64. Marshall S. Shapo, The LAW Of ProduCtS LIABILITY § 12.04[4], at 12-47 (3d ed. 1994) (quoting E mbs v. Pepsi-C ola B ottling C 0., 528 S.W .2d 703, 706 (K y. 1975)).

65. See id.; see also E mbs, 528 S.W. 2 d at 706. 
good position both to evaluate the qualifications of the providers with whom they contract and also to demand contract terms, such as participation in quality assurance activities, that will promote consumer safety. ${ }^{66}$ Particularly where the $\mathrm{MCO}$ has a direct contractual relationship with consumers and advertises to the public, it is likely to induce brand-name reliance that further justifies an obligation on its part to stand behind its product.

Moreover, as the seller of a package of financial and medical services, an M CO cannot avoid shaping the quality of those services. If it is to receive any benefit from its organizational structure, it must, at a minimum, contract with some providers and not others and settle on a mechanism for paying them. $E$ ven these basic decisions can be quite significant. For example, an MCO might select providers solely on the basis of their willingness to make price concessions without regard to their reputation for quality, and its decisions about the size and composition of its provider network will affect its members' access to both primary and specialty care. ${ }^{67}$ The payment mechanisms it uses will create financial incentives that will powerfully affect physician decisions in many cases. $^{68}$

Whether they elect to use their authority or not, M COs are in a position to enhance the quality of care their members receive or to undermine it: MCOs can monitor provider performance only with a view to the plan's bottom line or they can use monitoring methods to improve quality; they can adopt practice policies to rationalize physician behavior or they can implement a capitated payment system and disclaim any further interest in "medical" decisions; they can limit referrals to specialists unduly, appropriately, or not at all. M CO s cannot avoid "interfering" in medical decision-making by adopting a "hands off" policy once their payment arrangements are in place; their policies will have already affected the identity of the medical decision maker, how and how much he will be paid, the setting in which treatment will be delivered, and other important components of the service.

66. Not only do MCOs regularly require participation in quality assurance activities, see, e.g., MANAGED CARE, supra note $1, \S 2.9 .2$ (describing typical PPO contract terms), they sometimes specifically tell a physician to make one medical decision and not another. Perhaps the most common example of such a directive would be a contractual requirement that a physician prescribe only from an approved prescription drug formulary. See, e.g., R ussell A. J ackson, M CO s A ccounting for a G rowing Portion of the Pharmacy Pie, M A NA GED CARE OUTLOOK, J une 27, 1997, although plans have also required participating providers to follow practice guidelines, and MCOs often have "policy manuals" affecting routine issues arising in medical practice. See A lice G. G osfield, M easuring Performance and Quality: The State of the Art and Legal Concerns, HEALTH LAW HANDBOOK 55-60 (1995); Julie A. J acob, Some I nsurers R evise M ammography Coverage Polices, A M. M E D. NE WS, M ay 19, 1997, at 5.

67. See generally J ohn Blum, The E volution of Physician Credentialing into M anaged Care Selective Contracting, 22 A M. J . L. MED. 173 (1996).

68. A health plan's decision to shift from fee-for-service payment to capitation, for example, radically changes the economic incentives facing physicians. WALTER A. ZELMAN, THE CHANGING HeALTH CARE MARKETPLA CE 49-67 (1996); Clark C. Havighurst, Making Health Plans A ccountable for the Quality of Care, 31 G A. L. REV. 587, 595-606 (1997); A ndrew Ruskin, Capitation: The L egal Implications of Using Capitation to Affect Physician Decision-Making Processes, $13 \mathrm{~J}$. CONTEMP. HEALTH L. \& POL'Y 391, 411-19 (1997). Some health plans are now experimenting with fine-tuning incentive payment mechanisms so that physicians would have economic incentives to adjust their behavior to take into account not only cost, but quality and consumer satisfaction as well. 
Where an M CO has engaged in the business of selling medical services and a patient is severely injured on account of a defect in those services (that is, medical negligence), the plaintiff's ability to recover should not depend on whether he can meet the rigid tests of vicarious liability law or prove that some cost-containment strategy or other practice of the MCO was negligent. The seller accountability principles confirm that when the MCO and its affiliated providers fail to provide services that conform to minimum quality standards, it should not fall to the plaintiff to determine which of the possible defendants is most responsible.

D efendants in implied warranty cases can be expected to argue that the appropriate analogy is not between MCOs and product manufacturers but rather between $\mathrm{MCO}$ s and retailers who are uninvolved in the manufacturing process. While this distinction would be irrelevant under the law of most states, some courts have been hesitant to impose liability on retailers with no means of influencing the product design or manufacturing process. ${ }^{69} \mathrm{~A}$ similar impulse has led some state legislatures to grant a degree of immunity to nonmanufacturing product retailers. $^{70}$

In light of the MCO's ability to influence the services it provides, the response to such arguments should be fairly obvious. E ven if scruples about strict liability would lead courts to absolve some nonmanufacturing retailers from liability for defective products, M CO liability should be unaffected. M CO s may be irresponsibly indifferent about the quality of services their physicians provide, $^{71}$ but they cannot persuasively argue that they exert no influence over the shape of those services. For this reason, legal rules (whether judge-made or statutory) that exonerate nonmanufacturing retailers should not apply to MCOs.

69. A s a general rule, retailers, like other commercial sellers are liable for product defects caused by other parties in the chain of distribution. RESTA TEMENT (THIRD) OF TORTS, supra note $6, \S 1$, cmt. e, (collecting cases and concluding that support for the rule that "any seller in the chain of distribution (manufacturer, wholesaler, retailer) is liable for the sale of a defective product is widespread"); cmt. 0 (nonmanufacturing sellers liable for defective design and inadequate instructions and warnings); DAVID F. FISCHER \& WILLIAM S. POWERS, PRODUCTS LIABILITY: CASES AND MATERIALS 588 (1988) ("The overwhelming majority of courts have followed the position taken in [V andermark $V$. Ford M otor Co., 391 P.2d 168, 171-72 (Cal. 1964)(en banc)] and cmt. f [to Section 402A ] by applying strict liability to retailers." ). N evertheless, some state statutes evince misgivings about holding retailers liable for manufacturing defects beyond their control, immunizing nonmanufacturing sellers from strict products liability altogether, see, e.g., GA. CODE A NN. §§ 51-11.1 (1997), or in the event the manufacturer is subject to the court's jurisdiction and is solvent, see e.g., TENN. CODE ANN. $\S \S 29-28-$ 106 (Supp. 1996). See generally A MERICA N LA W OF PR ODU CTS LIA BILITY, supra note 61, §§ 5:14-5:19 (analyzing various state statutes). $M$ any of the statutes conferring immunity speak in terms of the retailer's ability to inspect products and suggest other analysis that is inappropriate in when services are being sold. See, e.g., Kan. Stat. A nn. § 60-3306 (1994). Cf., SHA PO, supra note 64, at § 12.04[2][b], 1240 ("If a thread of consistency exists in results that go both for and against retail sellers, it may reside in the degree of consumer reliance on the defendant [and] in the retailer's opportunity to exercise control over risk.").

70. See supra note 69 .

71. Cf. Havighurst, supra note 68, at 619 n. 80 ("Because of the need to induce better oversight and to increase selectivity, an M CO's failure to exercise any control over the negligent doctor is a better reason to impose enterprise liability than not to." ). 
III

TOWARD AN IMPLIED WARRANTY OF QUALITY: POLICY ISSUES

\section{A . R evisiting E nterprise Liability Policy}

The preceding section argues that, contrary to prevailing assumptions, existing law supports an implied warranty of quality that obligates M CO s to sell medical services that satisfy the existing malpractice-based standard of care. Indeed, considering the lengths to which courts have gone to protect consumers against personal injury in consumer product transactions, MCOs' lack of accountability constitutes a striking departure from "normal" law. This section considers the policy implications of holding MCOs to an implied warranty of quality. It begins with a brief examination of the implied warranty in light of the major policy concerns of tort law-deterrence, compensation, efficiency, and fairness. The bulk of this section is then devoted to a comparison of the implied warranty of quality with other common law theories of M CO liability.

A substantial body of literature endorses M CO liability for physician malpractice from a policy perspective. ${ }^{72}$ This literature developed primarily in connection with various legislative proposals for "enterprise medical liability," especially the proposal of President Clinton's H ealth Care Task Force. A Ithough these legislative proposals differ in some respects from the implied warranty of quality advocated here, most commentators have concluded that imposing automatic liability on MCOs for the malpractice of their physicians would represent a significant improvement over the status quo. ${ }^{73}$

The case for focusing liability on MCOs is straightforward and consistent with the policies underlying enterprise liability in the products context. ${ }^{74}$ First

72. See 2 The A MERICAN LAW INSTITUTE, REPORTER'S STUdY: ENTERPRISE RESPONSIBILITY FOR PERSONAL I NJURY 111-26 (Paul C. Weiler ed. 1991) [hereinafter A LI REPORTERS' STUDY ]; K enneth S. A braham et al., Enterprise Responsibility for Personal Injury: Further Reflections, 30 SA N DIEGO L. REV. 333 (1993); K enneth S. A braham \& Paul C. W eiler, Enterprise M edical L iability and the Choice of the Responsible E nterprise, 20 A M. J . L. \& MED. 29 (1994)[hereinafter Choice of the Responsible Enterprise]; A braham \& Weiler, Enterprise Medical Liability, supra note 2, at 382-84; Havighurst, supra note 68; William M. Sage et al., Enterprise Liability for M edical Malpractice and Health Care Quality Improvement, 20 A M. J . L. \& MED. 1 (1994); Paul C. Weiler et al., Proposal for M edical L iability Reform, 267 J. A M. M ED. A SS'N 2355 (1992). But see Patricia M. Danzon, Tort L iability: A M inefield for M anaged Care?, 26 J. LEG. STUD. 491 (1997). The A LI Reporters' Study proposed hospital-based, rather than health-plan-based enterprise liability. 2 A LI REPORTERS' STUDY, supra, at 113. However, its authors acknowledge that either strategy would represent an improvement over the status quo. See A braham \& W eiler, E nterprise M edical L iability, supra note 2, at 415 . For a debate over the merits of delivery-based versus finance-based enterprise medical liability, see id. at 415-19; A braham \& W eiler, Choice of the Responsible E nterprise, supra; Sage et al. supra.

73. See generally Sage et al., supra note 72; A braham \& W eiler, E nterprise M edical L iability, supra note 2 , at 415 .

74. These include, for example, protecting consumers from avoidable injuries. See E scola v. CocaCola B ottling Co. of Fresno, 150 P.2d 436, 441 (Cal. 1944) ("It is to the public interest to discourage the marketing of products having defects that are a menace to the public."); KEETON ET AL., supra note 26, § 98, at 693 (citing Phillips v. K imwood M achine Co., 525 P.2d 1033, 1041-42 (O r. 1974); First National Bank of A lbuquerque v. Nor-A m A gricultural Products, Inc., 88 N.M. 74, 537 P.2d 682 (1975)), assuring their compensation when such injuries occur, see E scola, 150 P.2d at 441, spreading losses efficiently, see id; Goldberg v. Kollsman Instrument Corp., 191 N.E.2d 81, 83 (N.Y. 1963); 
and foremost, MCO liability is likely to reduce preventable medical injuries. Individual malpractice premiums are almost never experience-rated; focusing liability on MCOs would permit experience rating (or its equivalent) at the MCO level and thus give MCOs additional economic incentives to prevent injuries. $^{75}$ In addition, MCOs are substantially better positioned than are physicians to engage in systematic efforts to improve quality. ${ }^{76}$ Institutional liability would also help rationalize MCO s' cost-containment mechanisms. A t present, MCOs that are not vicariously liable for provider malpractice have only attenuated economic incentives to consider the likelihood that MCO policies might contribute to negligent physician decision-making and patient injury. ${ }^{77}$ If MCOs were automatically liable for physician negligence, they would have an additional incentive to consider the likelihood that a payment mechanism or other policy would increase the M CO 's liability.

Greenman v. Y uba Power Products, Inc., 377 P.2d 897, 901 (Cal. 1962); G reenfield, supra note 11, at 688 , skepticism about consumers' ability to evaluate increasingly complex products, see G reenman, 377 P.2d at 901; D avid G. O wen, The Intellectual Development of M odern Products Liability Law: A Comment on Priest's V iew of the Cathedral 5 F oundation, 14 J. LEGA L STU D. 529 (1985), skepticism of their ability to bargain effectively with distant corporate sellers, see Priest, supra note 12 , at 520 , the unfairness of applying caveat emptor in the face of sophisticated marketing campaigns, see generally id; see also G regory C. K eating, The I dea of Fairness in the $L$ aw of $E$ nterprise $L$ iability, $95 \mathrm{MICH}$. L. REV. 1266 (1997); D avid G. O wen, The M oral Foundation of Product L iability L aw: Toward First Principles, 68 N OTRE DAME L. REV. 427 (1993), and the undue cost of litigating the fault issue, see KEETON ET A L., supra note 26, at 693 (citing Phipps v. G eneral M otors Corp., 363 A .2d 955 (M d. 1976)); G reenfield, supra note 11 , at 688 .

75. See A L I REPORTER S' STUdY, supra note 72, at 123-24; A braham \& W eiler, E nterprise M edical L iability, supra note 2, at 410-15; H avighurst, supra note 68, at 618 n. 79 ("A n important practical consideration strongly arguing for enterprise liability is that $\mathrm{MCO}$, if they were routinely liable for physician torts, would have stronger financial incentives to maintain quality than do individual physicians, who generally carry liability insurance that cushions the effect of any judgment and is not sufficiently experience-rated to cause the doctor to recognize or modify risky behavior.").

76. See Havighurst, supra note 68 , at 619 n. 80 ("Because of the need to induce better oversight and to increase selectivity, an M CO's failure to exercise any control over the negligent doctor is a better reason to impose enterprise liability than not to."); Sage et al., supra note 72, at 11-12 (noting health plans' ability to influence care through contractual arrangements with providers and "gatekeepers"), 14 ("H ealth plans should be more efficient quality managers because institutions are better able than individual practitioners to view the quality of care they deliver in the aggregate, have the financial resources to develop medical information systems, and can more easily implement programs for 'total quality management' (TQM) or 'continuous quality improvement' (CQI)."), 15 (noting health plans' ability to facilitate physician-patient communication and thereby reduce malpractice exposure, to identify and deal with substandard practitioners, and provide consumers with better information); William M. Sage \& J ames M. J orling, A World That Won $t$ Stand Still: E nterprise L iability By Private Contract, 43 D EPA U L L. R E V. 1007, 1016 (1994) (“[E ]xisting managed care contracts can address quality monitoring, clinical performance, accountability for error and dispute resolution procedures." ), nn. 56-60 (providing sample contractual provisions); but see Sage et al., supra note 72, at 23 (recognizing that some MCOs "may not be immediately capable of performing good quality control"). See generally Barry R. Furrow, The Changing Role of the L aw in Promoting Q uality in Health Care: From Sanctioning O utlaws to M anaging O utcomes, 26 H O U STON L. R EV . 147 (1989).

77. M CO s have a market incentive to do so, but consumers' lack of information about plan quality reduces this incentive. Patients that are injured may also incur additional medical costs which the plan must cover. See Sage \& J orling, supra note 76, at 1017 (1994) (reporting that additional medical expenses caused by medical malpractice comprise about 25 percent of all damages). In addition, some cost containment mechanisms might constitute direct negligence on the M CO's part.

78. See Sage et al., supra note 72 , at 7 ("If the organizational unit responsible for delivering cost- 
In addition, M CO liability would facilitate compensation for the relatively small number of injured plaintiffs who are entitled to damages that exceed the policy limits of their physicians' professional liability insurance policies. ${ }^{79} \mathrm{M}$ ore significantly, because M CO s will often serve larger risk pools than are available to conventional physician malpractice insurers, MCO malpractice insurance should be subject to more efficient underwriting than individual professional liability policies. ${ }^{80}$ The comparative advantage of M CO s as risk-bearers creates an incentive for physicians and MCOs to bargain for wealth-increasing indemnity and insurance arrangements. ${ }^{81}$

Litigating the issue of M CO liability is also likely to be wasteful. Litigation over whether the negligent physician was the (actual or apparent) agent of the MCO or over whether the MCO was independently negligent makes malpractice litigation costly ${ }^{82}$ and may have a chilling effect on the M CO's quality assurance procedures. ${ }^{83}$ In addition, if M CO s were automatically liable for physician negligence, many of the costs associated with multiple-defendant litigation-such as increased legal fees, the monitoring of costs, and the difficulties associated with settlement ${ }^{84}-$ might be eliminated by contractual indemnities between the MCO and its providers.

M CO liability is also appropriate as a matter of fairness. ${ }^{85}$ Indeed, misgiv-

effective care does not suffer financial loss when its attempts to control utilization result in more severe morbidity, it will fail to take appropriate precautions in designing and implementing costcontainment policies.").

79. See A braham \& Weiler, E nterprise M edical L iability, supra note 2 , at $391 \& \mathrm{n} .41,402-03 \& \mathrm{nn}$. 81-82.

80. Malpractice insurers' risk pools are relatively small because they are limited to physicians who (1) practice the same specialty (2) in the same state (3) that have coverage with the particular insurer. See A braham \& W eiler, E nterprise M edical L iability, supra note 2, at 401.

81. O ne might well ask why, if this is true, MCOs and their physicians have not already contracted for MCO s to bear malpractice liability. See, e.g., Danzon, supra note 72 , at 515 . O ne possible answer is that reorganizing the fee structure and existing insurance mechanisms would be unduly costly to loosely affiliated MCOs given their existing immunity from liability. Cf. A LI REPORTERS' STUDY, supra note 72, at 121 (describing "the major transaction costs of reconstructing all the reimbursement schedules [as] a potent inertial force in favor of the legal status quo"). Note that such contractual arrangements are in fact sometimes observed when an institution is automatically liable for its providers' negligence. See Sage et al., supra note 72, at 17-18 (describing "channeling" arrangements in teaching hospitals and voluntary assumption of liability by some M CO s and other entities); Sage \& J orling, supra note 76, at 1034-37 (same).

82. Cf. A braham \& W eiler, Enterprise M edical Liability, supra note 2, at 391-92 (evaluating effects of proof requirements in litigation against hospitals). B ecause plaintiffs seeking to hold MCOs and hospitals liable for a physician's malpractice generally employ the same legal theories, see $\mathrm{H}$ avighurst, supra note 68 , at 607 , the same analysis applies.

83. See A braham \& W eiler, E nterprise M edical L iability, supra note 2, at 392 (analyzing hospital litigation). The similarity of peer review mechanisms in hospitals and M CO s suggests that this observation applies equally to MCOS.

84. See A LI REPORTERS' STUDY, supra note 72, at 119; A braham \& W eiler, Enterprise M edical L iability, supra note 2, at 406; $\mathrm{H}$ avighurst, supra note 68, at 606; Sage, et al., supra note 72, at 19.

85. See Barry R. Furrow, M anaged Care O rganization and Patient I njury: R ethinking L iability, 31 GA . L. REV. 419, 457 (1997); V ernellia R . R andall, M anaged Care, Utilization Review, and Financial Risk-Shifting: Compensating Patients for $\mathrm{H}$ ealth $\mathrm{C}$ are Cost-C ontainment Injuries, $17 \mathrm{U}$. PU GET SOUND L. RE V . 1, 8 (1993); but see A braham \& W eiler, Enterprise M edical L iability, supra note 2, at 399-400 (arguing that "individual physicians do not 'correct' any particular 'injustice' they may have commit- 
ings about the legitimacy of managed health care as a means of providing medical services are magnified by MCO s' lack of tort accountability. ${ }^{86}$ M CO s exert tangible control over physician behavior, both directly-through medical policies and directives ${ }^{87}$ - and indirectly-through payment methodologies ${ }^{88}$ and the threat of deselection. ${ }^{89}$ M CO policies can also affect the medical care patients receive even when such policies do not affect physician behavior. By contracting with only a select group of providers in any given community, an M CO either restricts use of, or gives its members incentives not to choose, providers whose services may be of higher quality, yet more expensive to the plan. A s explained in some detail below, the vicarious liability analysis courts routinely employ in MCO liability cases makes it quite difficult for patients to hold MCOs accountable even when their policies directly contribute to physician negligence.

O ne may anticipate a number of policy arguments against imposing an implied warranty of quality on MCOs. The first is an extension of the critique of products liability law offered by George Priest and others challenging the manufacturing enterprise's efficiency as a risk-spreader, its capacity to respond optimally to the safety incentives created by the tort regime, and the existence of meaningful information and bargaining power problems in consumer product transactions. ${ }^{90}$ Whatever the ultimate force of this critique in the products liability context, ${ }^{91}$ arguments alleging over-deterrence and inefficient manda-

ted").

86. H avighurst, supra note 68 , at 590-95.

87. See generally supra note 66 .

88. See generally supra note 68.

89. The threat of "deselection" is an important source of economic leverage over physicians. See J ohn D. Blum, The Evolution of Physician Credentialing into M anaged Care Selective Contracting, 22 A M. J. L. \& MED. 173, 195 (1996). A s long as patients covered by any given payor do not represent too great a proportion of a physician or group's practice, the threat of deselection may exert only a mild influence. Where a plan has a large market share or where a physician is otherwise dependent on a particular plan, however, exclusion can spell financial ruin. Highly developed information systems now enable plans to develop detailed profiles of the services physicians order for plan patients. Cost and quality profiling increasingly serve as the basis upon which plan administrators decide with which physicians they will contract. See, e.g., Linda O. Prager, Oxford's Gambit: Specialist Teams, DoctorSpecific D ata, A M. M ED. NEWS, M ay 19, 1997, at 1. In addition, health plans appear more willing to contract with a large number of providers when they are attempting to establish a presence in a given market; once the plan's market share develops, they may find it advantageous to reduce the size of their networks in order to reduce administrative costs and in order to negotiate more favorable payment terms with the remaining providers. Especially in areas where there is a surplus of physicians, loss of participating provider status can have dramatic economic effects on a physician. Physicians may thus have strong incentives to conform to plan expectations concerning utilization of services, even if a plan has relatively few explicit mechanisms in place to control physician treatment patterns. See generally $U$ we R einhardt, Reorganizing Financial Flows in A merican Health Care, HEALTH AfF. 172 (Supp. 1993) (describing effect of M CO s on physician labor markets).

90. See, e.g., G eorge L. Priest, The Current Insurance Crisis and M odern Tort L aw, 96 Y A LE L.J . 1521 (1987); George L. Priest, M odern Tort L aw and its Reform, 22 V A L. U. L. REV. 1 (1987); A Ian Schwartz, P roposals for Products L iability Reform: A Theoretical Synthesis, 97 Y A LE L .J 353 (1988).

91. See Steven P. Croley \& J on D. H anson, Rescuing the R evolution: The Revived Case for E nterprise L iability, 91 M ICH. L. REV. 683 (1993) (defending enterprise liability against efficiency critique); Gregory C. Keating, The Idea of Fairness in the L aw of Enterprise Liability, 95 M ICH. L. REV. 1266 
tory insurance lose some of their force given the implied warranty's use of a negligence standard as the benchmark against which MCP services are to be measured. To be sure, M CO liability for physician negligence is "strict" in the sense that proof of direct negligence on the part of the MCO is not required. H owever, even in this regard, the implied warranty bears a much stronger resemblance to the relatively noncontroversial principles of corporate vicarious liability than it does to the defect-oriented inquiry of products liability law. ${ }^{92}$

O ne might also expect a slippery slope challenge to the implied warranty, arguing that it could not be coherently limited to M CO s and would thus expose service firms in other sectors to unwarranted liability. This objection is unlikely to be of practical significance. First, the tort-based implied warranty advocated here applies only to personal injury claims. Moreover, given its origins in the unusual hybrid tort-and-contract theory of traditional malpractice law, the implied warranty may well be considered sui generis. In addition, most firms that sell services use employees rather than independent contractors to do so and are thus already liable on theories of actual or apparent agency for those employees' torts. Finally, even a firm that resells the services of independent contractors will often be held liable for its contractor's negligence under the nondelegable duty doctrine if rendition of the services involves a substantial risk of personal injury to consumers. ${ }^{93}$

Significantly, the consumer protection effects gained by imposing a warranty on M CO s could be achieved without substantially diminishing consumers' choices in the marketplace. Providers and consumers that objected to the degree of corporate intervention in health care that would follow automatic M CO liability could choose a traditional indemnity insurance product that allowed free choice of physician and that relied on traditional utilization review to contain costs. The only option that would become harder to find in the market would presumably be managed care products offered by MCOs with a "handsoff" attitude toward quality assurance. A t present, it is difficult to see why a consumer would prefer a health plan that could take quality-decreasing costcontainment measures without regard to resulting personal injuries. ${ }^{94}$ Indeed, one suspects that such plans trade on the frequent misperceptions (willfully created in the days when medicine was privately regulated by the medical profession) that all medical care is created equal, so that consumers do not under-

(1997) (defending enterprise liability on fairness grounds).

92. For a critical appraisal of the policy justifications underlying vicarious liability law, see G ary $T$. Schwartz, The Hidden and Fundamental I ssue of E mployer Vicarious L iability, 69 S. CA L. L. REV . 1739 (1996).

93. The nondelegable duty doctrine is considered in Part III.B.3. infra.

94. O ne reason might be the deep pocket effect of $M C O$ liability. See infra text accompanying notes 108 through 110. This might conceivably raise the price of M CO coverage by an amount greater than the quality gains the M CO could accomplish with aggressive management. Consumers might also rely on the market as a quality assurance check on MCO cost containment policies with bad quality effects. H owever, information problems cast doubt on this strategy. 
stand that they are getting lower quality medicine for their lower premium. ${ }^{95}$

A nother plausible objection to the implied warranty of quality is that it may well be a second-best solution to the problem of MCO immunity. B ecause it is a judge-made remedy, it would differ from legislative proposals for enterprise medical liability ("EM L") in that it presumably would not make M CO s exclusively liable for physician malpractice. Exclusive MCO liability is arguably preferable from an efficiency perspective because M COs are likely to be more efficient insurance purchasers than physicians, and because litigation costs would be reduced if only one entity were the target of each malpractice suit. ${ }^{96}$ Providers who are not relieved of malpractice liability may need to continue purchasing individual professional liability coverage, reducing potential efficiency gains. ${ }^{97}$

A Iso, if physicians remain liable for malpractice, M CO s may elicit promises of indemnity from affiliated doctors, thereby reducing the M CO's incentive to take all reasonable steps within its power to improve the quality of the services it sells. ${ }^{98}$ Finally, doctors that face continued liability may be more likely to resist reasonable cost-containment measures on defensive medicine grounds, and some of the potential for improvement in relations between corporate managers and health care professionals may be lost. ${ }^{99}$

On the other hand, the increased cooperation between M CO physicians and corporate managers intent on increasing the bottom line that would presumably result from statutory E M L proposals is not an unmixed blessing. O ne benefit of a common law warranty is that it continues the physician's malpractice liability and thus his incentive to advocate for the patient. ${ }^{100}$ The very nature of corporate medical practice suggests that physicians will have personal incentives not to resist corporate directives to control costs. Continuing physician liability for medical malpractice, including a duty to advocate for patients within the plan's administrative framework ${ }^{101}$ will provide at least some coun-

95. This problem may be exacerbated by the employees' financial incentives to minimize health care costs. See D ayna B. M atthew, Controlling the R everse A gency C osts of E mployment-B ased $H$ ealth Insurance of M arkets, C ourts, and a Regulatory Quagmire, 31 W A KE FOREST L. REV . 1037 (1996).

96. See Sage et al., supra note 72, at 19-20; A braham \& W eiler, E nterprise M edical L iability, supra note 2 , at 406 .

97. See A braham \& W eiler, Enterprise M edical L iability, supra note 2, at 420-21 (arguing that hospital-based enterprise liability should extend to services provided outside the hospital for this reason).

98. See Sage et al., supra note 72 , at 21 (arguing that E M L schemes should forbid indemnification of M COs by physicians).

99. See id. at $12-13$ (arguing that one of the virtues of enterprise medical liability is its potential to improve MCO/physician relations).

100. But see A LI REPORTERS' STUDY, supra note 72, at 121-26 (arguing that exclusive enterprise medical liability need not make physicians indifferent to the quality of care they provide).

101. See Havighurst, supra note 68, at 640-43 ("[A ] doctor should be expected to advocate dutifully and competently, within whatever machinery the plan provides, any plausible claim the patient might have to have a needed service paid for by the plan, calling all relevant information to the attention of the utilization manager."); see also Wickline v. State, 192 Cal. A pp. 3d 1630, 1645-46 (Cal. Ct. A pp.), review granted, 727 P.2d 753 (Cal. 1986), review dismissed and case remanded, 741 P.2d 613 (Cal. 1987). 
terweight to the pressure corporate managers will inevitably exert. While a fully adversarial relationship may not be desirable, the A chilles' heel of managed health care may well be its tendency to undermine physicians' loyalty to their patients. R etention of malpractice liability certainly will not alleviate this problem entirely, but it may help provide needed reinforcement of this important professional ethic.

A nother reason not to be concerned about the alleged inefficiency of the implied warranty of quality as compared with legislative E M L proposals is that exclusive M CO liability can be implemented by contract. ${ }^{102}$ M CO s could simply agree to indemnify their providers completely against medical malpractice claims. ${ }^{103}$ While the providers would still face formal liability and the embarrassment of malpractice litigation, indemnities would probably enhance cooperation between MCO s and providers. Indeed, many teaching hospitals, which are more likely to have actual master/servant relationships with their physicians and thus to be liable for their torts, currently employ channeling and other arrangements that substantially resemble E M L by contract. ${ }^{104}$

The implied warranty of quality might also be criticized as a "second-best" prescription for M CO accountability in light of the deficiencies of the malpractice system. ${ }^{105} \mathrm{M}$ alpractice law is a blunt instrument; questions of medical fault push jury competence to the limit, and many people assume juries are incapable of making the cost-benefit tradeoffs that are implicit in the very concept of managed health care. ${ }^{106} \mathrm{G}$ iven these limitations, why place additional reliance on malpractice law?

The question should not be framed as whether the implied warranty standing alone is the ideal solution to the new malpractice problems presented by managed care. R ather, the warranty must be compared in the first instance to courts' other options for dealing with questions of M CO accountability. I have argued that the implied warranty is superior to a rule of no accountability from both a positive and a normative perspective, and I will argue below that it is

102. See generally Sage $\&$ J orling, supra note 76, A braham $\&$ W eiler, E nterprise M edical L iability, supra note 2 , at 429 .

103. In some cases, indemnities might well run in favor of the M CO. Some institutional providers such as hospitals may be more efficient risk bearers than some M COs. Sage et al., supra note 72, at 23. Indeed, the joint and several liability which an implied warranty would create might facilitate efficient contractual arrangements that might not occur under "exclusive" enterprise medical liability proposals. See id. (arguing that emerging M CO s might lack the bargaining power required to get more efficient institutional risk bearers to assume liability and suggesting a transition period of joint and several liability among MCO s and other institutional service providers).

104. See Sage et al., supra note 72, at 17-18; Sage \& J orling, supra note 76, at 1026 . A "channeling" arrangement involves a health care enterprise purchasing malpractice insurance for affiliated and employed physicians. Thereafter, affiliated physicians do not carry individual medical malpractice insurance, but, instead, are covered under the health care enterprise insurer. The result is that when a suit arises, there is one insurer for both the physician and the health care enterprise.

105. See, e.g., Gary T. Schwartz, A National Health Care Program: What Its Effect Would Be on A merican Tort L aw and M alpractice L aw, 79 CoRN. L. REV. 1339, 1373 (1994) (noting that malpractice law is a possible solution to problems created by health care cost-containment, but questioning whether it is an intelligent solution).

106. Seeid. 
comparatively superior to other existing legal doctrines. H owever, combining the implied warranty with, say, regulatory or contractual mechanisms for approving specific cost-benefit tradeoffs might ultimately prove desirable. ${ }^{107}$

A final drawback of the implied warranty of quality may be its tendency to increase costs by inducing malpractice litigation that would otherwise not occur. While many patients feel a natural resistance to sue their personal physicians, there is reason to believe they may be less reticent if the potential defendant is a large corporation. Of course, a patient's reticence about bringing suit is not always warranted, so some portion of any increase in the number of lawsuits brought against MCOs may well represent an improvement in the system. ${ }^{108} \mathrm{~N}$ evertheless, there is a widespread and potentially justified concern that the cost of health care might be increased needlessly by a proliferation of either meritless litigation, excessive damage awards, or both. ${ }^{109}$

Despite these difficulties, the choice to be made is not necessarily between continuing unwarranted M CO immunity and opening the floodgates of abusive litigation. The "deep pocket" issue affects all types of businesses that operate in corporate forms. A s courts and legislatures move to resolve the controversy over large and unpredictable damage awards, the solutions they develop should affect litigation against health care firms no less than any other business enterprise. $^{110}$

\section{B. M CO Liability in the Courts}

MCO liability for physician negligence is not only good policy; it is also

107. See id. at 1347.

108. See Sage, et al., supra note 72 , at 19 (arguing that one benefit of enterprise medical liability is reduction in transaction costs facing injured plaintiffs).

109. See M ichael R ustad \& Thomas K oenig, Reconceputalizing Punitive Damages in M edical Malpractice: Targeting A moral Corporations, Not "M oral M onsters," 47 R UTGERS L. REV. 975, 1015-17 (1995) (arguing generally that concern over excessive punitive damage awards is unjustified in light of empirical studies, but conceding that "[0]verkill may become an issue in future cases involving HMOs"); but see NeIL VIDMAR, Medical MaLPRACTICE AND the AMERICAN JURy: CONFRONTING THE MYTHS ABOUT JURY INCOMPETENCE, DEEP POCKETS AND OUTRAGEOUS DAMAGE A WARDS 259-61 (1995) (concluding that empirical research "does not support the widely made claims that jury damage awards are based on the depth of defendants' pockets, sympathies for plaintiffs, caprice or excessive generosity"). A t present, punitive damages do not constitute an important element of health care costs. See PA UL C. WeILER, MEdICA L MALPRACTICE ON TRIAL 4 (1991); Rustad \& K oenig, supra, at 989 . E rratic damages do appear to present a problem. See K enneth $S$. A braham et al., Enterprise Responsibility for Personal Injury: Further Reflections, 30 SA N D IEGO L. REV. 333, 339 (1993); Thomas B. M etzloff, R esolving M alpractice D isputes: Imaging the Jury's Shadow, 54 LA W \& CONTEM P. PR OBS. 43, 84-88 (W inter 1991); Paul C. W eiler, Fixing the Tail: The Place of M alpractice in Health Care Reform, 47 RUTGERS L. REV. 1157, 1173-74 (1995). A Ithough it is impossible to predict how the introduction of corporate defendants will affect malpractice litigation, anecdotal evidence does suggest cause for concern that large damage awards might have a non-negligible effect on health care costs. See, e.g., Fox v. Health Net, No. 219692 (Riverside Co. Sup. Ct., Dec. 28, 1993) (jury awarded $\$ 12$ million compensatory damages and $\$ 77$ million punitive damages in connection with H MO medical director's refusal to authorize bone marrow transplant).

110. See, e.g., A braham \& W eiler, E nterprise M edical L iability, supra note 2, at 404-06 (advocating pain and suffering damages guidelines); Sage et al., supra note 72, at 21-22 (suggesting cap on noneconomic damages). In addition, the implied warranty theory could potentially reduce litigation over the legitimacy of payment mechanisms. 
good law, especially when compared to other legal mechanisms for holding MCO s accountable for medical malpractice. The most obvious doctrinal alternative to the implied warranty of quality is a broadening of existing vicarious liability rules in order to reach MCO defendants. ${ }^{111}$ As explained earlier, MCO s are presently liable for physician malpractice only when an actual or apparent employment relationship exists, when the MCO is itself negligent, or in a few other exceptional circumstances, such as when the principal's duty is deemed to be nondelegable or when the activity involved is abnormally dangerous. Several courts and commentators have proposed either expanding the existing tests for actual or apparent control or including medical practice in one of the "exceptional" categories. While either of these strategies would represent an improvement over the status quo, they are inferior alternatives to the implied warranty.

1. Expanding the "Control" Test. Historically, respondeat superior has rarely been applied to hold a corporation liable for the malpractice of physicians who are not its full-time employees. ${ }^{12}$ The touchstone of vicarious liability is control, defined primarily in terms of "the details of the work," and the skill and financial independence of the contractor. ${ }^{113}$ Because of traditional cultural assumptions about physician autonomy, the high degree of skill required for medical practice, and the differing circumstances of individual patients, managerial control over the physical details of medical practice has been considered both impractical and unethical. ${ }^{114}$ M oreover, most physicians

111. See G lenn, supra note 2, at 339 (arguing that the "same effect" of enterprise liability "may be achieved by applying medical tort principles to ... integrated networks").

112. But see, e.g., Schleier v. K aiser Found. Health Plan, 876 F.2d 174 (D.C. Cir. 1989) (staff-model H M O held liable for malpractice of non-employee physician); D unn v. Praiss, 606 A .2d 862 (N.J. Super. Ct. A pp. Div. 1992), subsequent proceedings, 638 A .2d 875 (N.J. Super. Ct. A pp. D iv. 1994), rev'd, 656 A .2d 413 (N.J. 1995) (H MO held liable for malpractice of non-employee consulting physician). Schleier and D unn are analyzed in some detail infra at text accompanying notes 150-61.

113. To determine whether a master-servant relationship exists under the R estatement test, courts are to determine the following facts, among others:

(a) the extent of control which, by agreement, the master may exercise over the details of the work;

(b) whether or not the one employed is engaged in a distinct occupation or business;

(c) the kind of occupation, with reference to whether, in the locality, the work is usually done under the direction of the employer or by a specialist without supervision;

(d) the skill required in the particular occupation;

(e) whether the employer or the workman supplies the instrumentalities, tools, and the place of work for the person doing the work;

(f) the length of time for which the person is employed;

(g) the method of payment, whether by the time or by the job;

(h) whether or not the work is a part of the regular business of the employer;

(i) whether or not the parties believe they are creating the relation of master and servant; and

(j) whether the principal is or is not in the business.

RESTA TEMENT (SECOND) OF A GENCY § 220(2)(a-j) (1958).

114. See David L. Leitner, Managed CARE LiABILITy 254-256 (1997); WALter A. ZeLman, the Changing health Care Marketplace, Private Ventures, Public InTerests 81-82 (1996); M ark A . H all, Institutional Control of Physician Behavior: L egal Barriers to $H$ ealth Care Cost Containment, 137 U. PA . L. R EV. 431, 463 (1988); H avighurst, supra note 68, at 587-88, 611; Theo- 
(even those affiliated in some way with MCOs) maintain independent and financially successful medical practices that serve patients with a wide variety of insurance coverages. ${ }^{115}$ As a result, physicians who are not salaried employees of an MCO are presumptively not under its control for vicarious liability purposes. ${ }^{116}$

A modified respondeat superior test presumably would approach the control issue from a more realistic vantage point, permitting injured plaintiffs to prove MCO control on the basis of existing, indirect control mechanisms, such as payment systems, market conditions, the threat of deselection and other similar factors. A Ithough a modified test would be an improvement over the status quo, it is problematic in several respects. First, the control inquiry is necessarily fact-specific, permitting MCOs that do not "control" their physicians to remain immune from malpractice liability. Such case-by-case linedrawing is likely to involve significant costs, especially additional litigation costs and increased uncertainty to no apparent advantage. Also, a factintensive control inquiry can be expected to encourage MCOs to distance

dore R. M armor et al., A N ew L ook at Nonprofits: H ealth Care Policy in a Competitive A ge, 3 Y A LE J. ON REG. 313, 313-17 (1986).

115. See generally, Robert A. Berenson, Beyond Competition, HEALTH AfF., Mar./A pr. 1997, at 171.

116. This is not to say that M CO s are incapable of "controlling" independent physicians. See supra note 66. A n M CO that regularly offers specific directions to an independent physician (such as through the use of formularies, practice guidelines or policy manuals) may run a significant risk of being found to "control the physical details of the employee's conduct." RESTATEMENT OF A GENCY, supra note $113, \S 220(2)(a)$. However, as described above, MCOs also use indirect means such as payment mechanisms, monitoring and the threat of deselection to influence physicians' practice. Compare Chase, 583 N.E.2d at 254 (no vicarious IPA liability despite presence of UR policies where "responsibility for the actual provision of medical treatment rests with [independent physician group] and its employee-physicians"), with Sloan, 516 N.E.2d at 1109 (medical director's judgments were final). O ne commentator has suggested that where cost-control mechanisms "are exercised by a physician-medical director or other medically trained personnel, the inference of control becomes even stronger." William A. Chittenden, III, M alpractice L iability and M anaged H ealth Care: $\mathrm{H}$ istory and Prognosis, 26 TORT A ND INS. L.J . 451, 457 (1991). Indirect mechanisms do not usually compel a physician to make any given medical decision, although they may increase the likelihood that he will do so. U nder the traditional control test, it is not enough that the principal's conduct be a substantial contributing factor in a given decision; control over the physical details of the employee's conduct must be proven.

E ven an M CO that occasionally directs physician decision making may be able to defeat allegations that it controls affiliated physicians. A s argued above, a principal can be deemed to control an independent contractor if it has the contractual right to control the contractor's decisions; actual control need not be exercised. MCO s' ability to get physicians to agree to abide by certain practice policies or to accept a prescription drug formulary might thus reasonably be held to indicate that MCOs possess the contractual ability to regulate physician practice, justifying liability. Even though this argument has considerable logical force, it would seem to be a hard sell as a practical matter. Despite the widespread corporate production of other goods and services in our economy, there is a strong cultural presumption that "only individual professionals, not corporations, provide health care." $\mathrm{H}$ avighurst, supra note 68. In order to prevail on the issue of M CO control, a plaintiff must overcome not only the MCO's proffered evidence of physician independence, but also existing cultural and legal presuppositions about the relative functions of physicians and corporations in the A merican health care industry. Id. Given these presuppositions, M COs may plausibly argue that their physicians' willingness to accommodate them on a modest range of practice issues should not permit an employmentlike control relationship to be inferred. 
themselves ${ }^{117}$ from medical decision-making in the hope of avoiding liability. This distancing could be real or only apparent. In the latter case, plans could include self-serving contractual language or adjust their organizational structures to cloud the control issue in litigation, exacerbating the cost and uncertainty problems identified above. M ore troubling, however, is the prospect that MCOs, after limiting their members' access to providers and instituting potentially dramatic cost-containment measures, will avoid using their economic leverage to maintain high quality standards on the theory that doing so would trigger tort liability. ${ }^{118}$

While judicial modification of the respondeat superior doctrine would be an improvement over the de facto immunity some MCOs now enjoy under the current version of the test, courts would be well-advised to look elsewhere for mechanisms of MCO accountability. Several courts have done so, holding M CO s accountable on the basis of ostensible agency and other related theories of vicarious liability. It is to these doctrines that we now turn.

2. O stensible A gency. Because it is easier to demonstrate an apparent master/servant relationship than a real one, several courts have used the doctrine of ostensible agency to hold MCOs vicariously liable for physician malpractice. ${ }^{119}$ An ostensible agency relationship does not require actual

117. See $\mathrm{H}$ avighurst, supra note 68 , at $587-89,608-18$.

118. See id. at $619 \mathrm{n}$. 80. The prediction that M CO s will distance themselves from medical decisions to consumers' detriment is illustrated by interest group activity in the political arena and in the courts. Organized medicine has steadfastly resisted legislative proposals to hold M CO s exclusively liable for physician malpractice on the ground that such proposals would give MCOs too great an incentive to control physician decisionmaking. Interestingly, however, the A merican M edical A ssociation and several other physician trade associations have established the A merican M edical A ssociation/Specialty Society M edical Litigation Project, a litigation resource center for which a prime objective is to persuade state courts to use vicarious liability doctrine to hold M CO s liable for the malpractice of independent physicians. A t first blush, the Project's work appears inconsistent with the A M A's opposition to enterprise liability. $Y$ et the two projects are, in fact, quite compatible. Because liability under respondeat superior and related doctrines turns on actual or apparent M CO control, organized medicine may hope to shape liability rules in such a way that M COs will be deterred from aggressively managing care.

$\mathrm{U}$ sing respondeat superior as the basis for evaluating M CO liability clearly serves the interests of organized medicine. While officially "neutral" on the question of managed care, the A M A is committed to defending physician autonomy in medical decisionmaking as against intrusion by corporate managers. $Y$ et it is not at all clear that an M CO's "hands off" policy is in consumers' best interests, especially once M CO payment mechanisms have created a financial conflict of interests between M CO physicians and their patients.

119. See, e.g., B oyd v. A lbert E instein M ed. Ctr., 547 A .2d 1229, 1235 (Pa. Super. 1988). The B oyd court granted summary judgment for the defendant H MO on the issue of whether the treating physicians were its ostensible agents on the basis of the following factors: (1) the M CO "operate[d] on a direct service rather than an indemnity basis"; (2) the decedent paid physician fees to the HMO rather than to the treating physician; (3) the decedent selected physicians from a list provided by the M CO (the list included only those who had been screened by the MCO and had agreed to follow MCO regulations); (4) MCO members could see a specialist only with their primary-care physician's approval; and (5) when specialty care was approved, M CO members had no choice as to the identity of the treating specialist. Id; see also M cClellan v. H ealth M aintenance O rg. of Pa., 604 A .2d 1053, 105658 (Pa. Super. Ct. 1992); D ecker v. Saini, N o. 88-361768 NH, 1991 W L 277590 (M ich. Cir. Ct. O akland County Sept. 17, 1991). Interestingly, the D ecker court allowed a vicarious liability claim against an M CO based upon the negligence of a nonparticipating specialist. But see Chase v. Independent Practice A ss'n, 583 N.E.2d 251, 255 (M ass. A pp. Ct. 1991) (rejecting plaintiff's vicarious liability claim 
control; rather, liability is appropriate where the MCO has made express or implied representations that independent contractor physicians are, in fact, its servants, and a plaintiff has reasonably relied upon those representations. ${ }^{120}$ If only because plaintiffs in ostensible agency cases enjoy a reduced burden of proof, cases predicating MCO liability on ostensible agency tend to be more doctrinally satisfying than those few cases that rely on respondeat superior to hold MCOs liable. Like respondeat superior, however, ostensible agency is ultimately an unsatisfactory test for determining whether an MCO should be held vicariously liable for physician malpractice.

The two most likely ways in which an MCO might make an express representation that an independent physician is its employee are its inclusion of the physician's name in its directory of participating providers and its designation of a primary care physician as coordinator of the care provided by the M CO if the M CO uses a gatekeeper model. While these representations are significant, they are probably insufficient to justify a finding of ostensible agency. First, neither of these facts is inherently inconsistent with an actual independent contractor relationship between the MCO and the physician. A s a result, the M CO may be able to negate reasonable reliance on the plaintiff's part by simply advising him of the true (that is, independent contractor) relationship between the MCO and its physicians at the time of enrollment. ${ }^{121}$ Moreover, in most communities, a single physician's name is likely to appear in several different provider directories. ${ }^{122}$ Where physicians in a given community are customarily affiliated with multiple networks, it would be unreasonable to draw an inference of agency from such a listing.

Plaintiffs may be more successful where an MCO's business structure amounts to an implied representation of control. A t one end of the spectrum of possible business arrangements, a plaintiff might contract with an M CO and be unaware of, or at least presumptively indifferent to, the identity of the pro-

against IPA because her M CO contract expressly stated the IPA was created to "arrange for" the provision of services to MCO members, not to provide those services itself); R aglin v. H M O Illinois, 595 N.E.2d 153, 157-58 (III. A pp. Ct. 1992) (finding no evidence that the plaintiff had relied on the M CO for the quality of health care she received, that the MCO had exercised control over its physicians' medical activities, or that it had held itself out as doing so).

120. See RESTA TEMENT OF A GENCY, supra note 113 , § 267 ("O ne who represents that another is his servant or other agent and thereby causes a third person justifiably to rely upon the care or skill of such apparent agent is subject to liability to the third person for harm caused by the lack of care or skill of the one appearing to be a servant or agent as if he were such."); RESTATEMENT (SECOND) OF TORTS, supra note $38, \S 429$ ("O ne who employs an independent contractor to perform services for another which are accepted in the reasonable belief that the services are being rendered by the employer or by his servants, is subject to liability for physical harm caused by the negligence of the contractor in supplying such services, to the same extent as though the employer were supplying them himself or by his servants.").

121. See Richard A . Hinden \& D ouglas L. E Iden, L iability Issues for M anaged Care E ntities, 14 SETON H A LL LEGIS. J. L . 1, 25 (1990); see infra text accompanying notes 138 through 140 (arguing that reliance element is essential to the concept of ostensible agency). But see $\mathrm{H}$ avighurst, supra note 68 , at $598 \mathrm{n} .31$ (arguing that many courts ignore reliance requirement and collecting cases).

122. See B erenson, supra note 115 , at 175 . 
fessionals who will provide the services. ${ }^{123}$ Instead, the patient looks to the MCO to provide or arrange for the provider of services of acceptable quality. A t the other end of the spectrum would be the traditional indemnity insurer. In the latter case, although the insurer pays the bills, the patient is clearly not relying on the insurer in connection with the quality of care he receives. ${ }^{124}$ $\mathrm{R}$ ather, the patient looks to the physician for medical services and the insurer for payment. M ost M CO s probably occupy a middle ground between these two poles. The plausibility of a consumer's claim that he was looking to the MCO rather than to a negligent provider for services will depend on the degree to which his choice of provider is restricted by the plan, the representations and advertising of the plan regarding its role in providing high quality health care, the controls the plan places on access to providers, and the degree of integration in the plan generally. ${ }^{125}$ The larger and looser the network of providers, the harder the claim of reliance on the MCO rather than the provider will be to sustain.

The main problem with the ostensible agency test is not that it never applies to MCO-provider relationships, but rather that (like respondeat superior) its fact-dependence needlessly increases the cost and uncertainty of the resulting litigation. Significantly, if the ostensible agency test is to be the chief means of holding M COs legally accountable to consumers for quality problems, such accountability is likely to become increasingly illusory, even when M CO s are engaging in cost containment measures with foreseeable adverse consequences for their patients. The reason the doctrine is likely to be ineffective against MCO s over the long run is that it makes liability turn on whether the plaintiff had reasonable grounds to misunderstand the nature of the $\mathrm{MCO}$-provider relationship. A s more courts use the ostensible agency doctrine to hold MCOs vicariously liable for provider malpractice, MCOs can be expected to include contractual language and other disclosures designed specifically to negate misunderstandings among plan members as to the independent contractor relationship between the plan and its physicians. ${ }^{126}$

Moreover, the doctrine cannot be coherently expanded to prevent MCOs from employing such a strategy. O stensible agency is an exception to the gen-

123. A s when, for example, a patient is a member of a tightly integrated, staff-model HMO.

124. Cf. M itts V. H.I.P., 478 N.Y.S.2d 910 (A pp. D iv. 1984) (holding indemnity insurer not liable for physician's malpractice).

125. See B oyd v. A Ibert E instein M ed. Ctr., 547 A .2d 1229, 1235 (Pa. Super. Ct. 1988). But see Raglin v. H M O Illinois, 595 N.E.2d 153, 157-58 (III. A pp. Ct. 1992).

126. See Clark C. Havighurst, Health CARe CholCes 118-20 (1995); Richard A. Hinden \& D ouglas L. E Iden; L iability I ssues for M anaged Care E ntities, 14 SE TON H A LL LE GIS. J ., 25-26 (1990). Generally, disclosure or disclaimers of agency relationships between the M CO and its providers may or may not be effective depending on the jurisdiction's emphasis on the actual reliance element. In theory if not in practice, the degree of reliance depends on whether the court is applying an ostensible agency theory, see RESTATEMENT (SECOND) OF TORTS, supra note 38 , § 429, which merely requires that services be accepted with the reasonable belief that the independent contractor is the defendant's agent, or an agency by estoppel theory, see RESTATEMENT OF A GENCY, supra note 113 , $\S 267$, which requires actual, detrimental reliance. However, a disclaimer shielded an IPA from malpractice liability in Chase v. Independent Practice A ss'n, 583 N.E .2d. 251, 254 (M ass. A pp. Ct. 1991). 
eral rule that a principal is not liable for the torts of independent contractors. ${ }^{127}$ A s noted above, the justification underlying the ostensible agency exception is that the principal has either induced or wrongfully permitted a plaintiff to infer the existence of a control relationship between itself and the independent contractor. The plaintiff's justifiable reliance on the principal's credit or reputation in engaging the independent contractor's services provides a basis for altering the implicit prior conclusion that the relationship between the principal and alleged agent is too attenuated to justify vicarious liability. U nfortunately for injured plaintiffs, the doctrine's conceptual structure leads inexorably to the conclusion that the ostensible agent's principal ought to be able to avoid liability by negating the plaintiff's reliance. Because the doctrine applies only between parties whose actual relationship, as a matter of law, cannot justify vicarious liability, the sole remaining basis for liability is the plaintiff's misapprehension of that relationship. ${ }^{128}$ If the plaintiff cannot reasonably be under a misapprehension of the principal's relationship with its independent contractor, the justification for departing from the general rule of nonliability under respondeat superior is completely removed.

A t least one court has strongly suggested its intention to resist any attempt by health care providers to avoid vicarious liability by advising their members that no actual agency relationship exists. ${ }^{129}$ O ther courts may do so sub silentio by denying summary judgment to MCOs where there is little factual basis for crediting a plaintiff's claim of apparent agency. A s a matter of policy and fairness, this sort of judicial conduct is understandable. The problem is the violence it does to ostensible agency as a legal doctrine. A s argued above, ostensible agency principles cannot be expanded to apply in situations where there is no reasonable appearance of a master-servant relationship. Indeed, a purported expansion would be a repudiation less of ostensible agency than of the broader rule that immunizes principals from liability for the torts of their independent contractors. If courts, out of concern about policy and fairness, are moving toward holding MCO s accountable for medical malpractice, an alternative legal doctrine will be required.

3. N ondelegable D uties. Of the vicarious liability rules, the most promising exception to the general rule of MCO nonliability for independent physician

127. O stensible agency "arises when a principal holds his agent out as possessing certain authority or permits him to exercise or to represent himself as possessing such authority." Nevada National Bank v. G old Star M eat Co., 514 P.2d 651, 653 (N ev. 1973). Furthermore, "[f]acts and circumstances are sufficient to establish [ostensible agency] only when a person exercising ordinary prudence [and] good faith ... would be misled thereby ...." Lamb v. General A ssocs., Inc., 374 P.2d 677 (W ash. 1962). O stensible authority of an agent can be inferred only from the acts and conduct of the principal. See R ESTA TEMENT OF A GENCY, supra note $113, \S 8$.

128. N ote that where an actual control relationship exists, a disclaimer is ineffective. See, e.g., Sanford v. Goodridge, 13 N.W.2d 40, 43 (I owa 1944) ("It will not do for an employer to make a contract which in many clauses loudly proclaims the independence of his contracting workman and in other clauses circumvents this granted freedom by retaining in himself all the control that employers ordinarily possess over their employees.").

129. See G rewe v. M ount Clemens G en. H osp., 273 N.W .2d 429, 435 (M ich. 1978). 
malpractice is the doctrine of so-called "nondelegable" duties. This doctrine holds that "the employer's enterprise, and his relation to the plaintiff [can be] such as to impose upon him a duty which cannot be delegated to an independent contractor." ${ }^{130}$ The principal's liability does not depend on a finding of fault. Instead, he will be held liable for his contractor's negligence even if no master/servant relationship or other basis for vicarious liability (such as ostensible agency) exists. No single defining characteristic exists that will identify a duty as nondelegable, other than facts suggesting that "the responsibility is so important to the community that the employer should not be permitted to transfer it to [an independent contractor]." ${ }^{131}$ Some courts have suggested that the doctrine applies to prevent businesses from delegating functions to independent contractors for the express purpose of avoiding responsibility for foreseeable personal injury. ${ }^{132}$

The nondelegable duty doctrine is less a rule of decision than a label courts apply when considerations of policy or fairness dictate that it is inappropriate to shield a principal from liability for an independent contractor's torts. ${ }^{133} \mathrm{Be}$ cause the nondelegable duty cases rest so strongly on policy, the rule could be easily used as a remedy for the M CO's unwarranted immunity without the conceptual difficulties associated with an expansion of ostensible agency doctrine. Indeed, the main problems associated with M CO immunity would be solved ${ }^{134}$ if courts began holding that M CO s that sell prepaid medical services (and not just financing) $)^{135}$ owe a nondelegable duty to provide non-negligent care to their customers. ${ }^{136}$

Despite the potential utility of the nondelegable duty rule in protecting health care consumers, courts have been slow to apply it against corporate sellers of health care services. The primary reason cited by courts in rejecting the doctrine is the traditional division of authority between doctors and hospitals. ${ }^{137}$

130. KEETON ET AL., supra note 26 , $\S 71$, at 511; see also RESTATEMENT OF A GENCY, supra note $113, \S 214$ (1958) ("A master or other principal who is under a duty to provide protection for or to have care used to protect others or their property and who confides the performance of such duty to a servant or other person is subject to liability to such others for harm caused to them by the failure of such agent to perform the duty.").

131. KEETON ETAL., supra note $26, \S 71$, at 512.

132. See, e.g., H annola v. City of Lakewood, 426 N.E.2d 1187, 1190 (O hio Ct. A pp. 1980) (“[P]ublic policy requires that the hospital not be able to artificially screen itself from liability for malpractice in the emergency room."). For examples of circumstances in which the doctrine has been applied, see KEETON ET AL., supra note 26, § 71 at 511-12.

133. See William L. Prosser Et Al., Ca Ses and Materials on Torts 650 (9th ed. 1994) (“In the last analysis, the cases represent ad hoc decisions that, as a matter of public policy, one cannot avoid particular responsibilities by hiring someone else to discharge them, because of the importance of the duty.").

134. See supra Part III.A.

135. See infra Part IV.

136. See Brewbaker, Managed Care Liability, in MANAGED CARE, supra note $1, \S 6.2 .2$ (arguing that non-delegable duty theory is superior to ostensible agency as a basis for MCO liability); $\mathrm{H}$ avighurst, supra note 68 , at 614 (arguing that the non-delegable duty doctrine provides a sound basis for M CO liability).

137. See Menzie v. Windham Community Mem'l Hosp., 774 F. Supp. 91, 95 (E.D. Conn. 1991) (holding that the only duty of a hospital is to provide a place for treatment); Petratos v. M arkakis, 637 
There may be other reasons for judicial reticence, however. In an era in which many state courts appear concerned about the appearance of judicial activism, the amorphous nature of the nondelegable duty rule may be a genuine obstacle to its implementation. Perhaps more importantly, it is hard to characterize an M CO 's decision to use independent physicians rather than employees to deliver medical services as a cynical attempt to delegate away liability for foreseeable personal injury. Indeed, as Clark $\mathrm{H}$ avighurst has pointed out, M CO s that contract with independent physicians are adhering to the longstanding legal presumption that corporations should not employ physicians, but that physicians should work only as independent contractors. ${ }^{138}$ This fact presents a formidable obstacle to the argument that MCOs should be penalized if they delegate judgments about medical decision-making to independent physicians.

\title{
IV
}

\author{
Putting TheORY INTO PRACTICE: A pPly ING THE \\ IMPLIED WARRANTY THEORY
}

\section{A. What is an $\mathrm{MCO}$ ?}

The preceding discussion of implied warranty theory has left an important practical question unaddressed: Given the proliferation of business entities in the health care industry, which ones should be subject to the implied warranty? This article argues that all MCOs (defined as firms that are in the business of selling or arranging for the sale of medical services) ${ }^{139}$ should be subject to the warranty. Under this proposed definition, a traditional indemnity insurance company would not be considered an $\mathrm{MCO}$, and thus would not be liable for physician malpractice, because it provides only financial, not medical, services. The policyholder is free to select treatment from any licensed health care provider of the services covered under the policy, and the insurer's review of medical decision-making is limited to determining whether the contract provides coverage. The insurer neither sells nor arranges for the sale of the medical services its insured will receive; it only commits to reimburse the insured for

N.E.2d 13, 15 (O hio Ct. A pp. 1993) (hospital has duty to grant staff privileges to competent physicians; therefore it is the duty of the physician to practice medicine non-negligently); Kelly $v$. St. Luke's H osp., 826 S.W.2d 391, 395 (M o. Ct. A pp. 1992) (rejecting idea that providing emergency room services is an inherently dangerous activity). One court concluded that decisions applying the nondelegable duty represent "misdirected attempts to circumvent the necessity of proving" liability based upon established agency principles. A Ibain v. Flower H osp., 553 N.E.2d 1038, 1047 (O hio 1990), overruled by Clark v. Southview H osp. \& Family Health Ctr., 628 N.E. 2d 46 (O hio 1994). A dditionally, the A lbain court held that "[t]he practice of medicine in a hospital by an independent physician with staff privileges does not involve the type of risks and precautions required as contemplated by the "non-delegable duty' exception." Id. at 1048.

138. See $\mathrm{H}$ avighurst, supra note 68 , at $632-33$.

139. A lthough this definition resembles a definition found in the Model HMO act, cf. NAIC MODEL LAWS, REGULATIONS AND GUIDELINES, MODEL HMO ACT §2(M) (1991), it is not intended to be limited to $\mathrm{HMOS}$, as discussed below. 
expenditures related to covered services at the rate provided for in the policy.

In stark contrast are tightly integrated sellers of medical services such as the staff model $\mathrm{HMO}$, perhaps the clearest example of an entity meeting the M CO definition. Staff-model HMOS sell the services of their physician-employees and associated professionals and institutions on a prepaid basis. M embers may receive care only from an $\mathrm{HMO}$ employee; the services of other physicians are not covered. The H MO both provides and finances its members' care. Like an insurance policy, HMOs protect their members from financial disaster in the event they need extensive medical care; member premiums create a pool of funds from which the cost of care can be satisfied. However, care is not provided through independent providers of the consumer's choice but is actually delivered by the $\mathrm{HMO}$ acting through affliliated institutions and professionals. ${ }^{140}$

Why should these two types of firms-the indemnity insurer and the $\mathrm{HMO}-$ be distinguished for liability purposes? The best way to answer this question is to understand the mechanisms by which MCO s have been able to undercut traditional health plans and gain market share. While some have argued that MCO success has been due primarily to adverse selection, ${ }^{141}$ the fact that MCO s actually sell medical services gives them important competitive advantages.

Consumers with traditional indemnity insurance purchase medical services directly from providers. The fact that they are insured reduces their incentive to control expenses. E ven unusually cost-conscious patients are unlikely to be effective negotiators because they have little economic leverage, and information about the cost and quality of alternatives in the marketplace will be available only at great expense. In contrast, MCO s can use the purchasing power of a large group of consumers to extract price concessions. Physicians and other providers that wish to compete for MCO members as patients must accept discounted reimbursement rates or risk being foreclosed from the MCO s' patient population. ${ }^{142} \mathrm{~A}$ Iso, M CO s can spread the cost of acquiring information over a larger pool of subscribers. N ot surprisingly, M CO s can and do fare better than individual consumers in negotiations with providers. ${ }^{143}$

O nce an MCO has assumed the position of "middleman" between consumer and provider, it cannot avoid influencing the quality of services it provides. This reasoning suggests that entities occupying a middle ground between tightly integrated HMOS and traditional indemnity insurance-for example, preferred provider organizations ("PPOs") and managed care plans offering a

140. See generally M ichele M. Garvin, H ealth M aintenance O rganizations, in M A NA GED CA RE, supra note 1 , at 1-1 to 1-239 (describing HM O s).

141. See J oseph P. Newhouse, Is Competition the A nswer?, 1 J. HEA LTH E CoN. 109 (1982); Gail R. Wilensky \& L ouis F. R ossiter, Patient Self-Selection in H M O s, 5 HEA LTH A FF., 66 (Spring 1986).

142. See Charles D. Weller, "F ree Choice" as a Restraint of Trade in H ealth Care D elivery, 69 I o WA L. REV . 1355-59 (1984) (distinguishing between "guild free choice" and "market free choice").

143. See $H$ arold $S$. L uft, P erspective and $E$ vidence on $E$ fficiency in $M$ anaged Care $O$ rganizations, in Competitive Mana ged CaRe: The Emerging HeALth CARE System 30, 35-36 (J ohn D. Wilkerson et al. eds. 1997). 
point of service option-should also be deemed to warrant the quality of their services. From a purely formalistic vantage point, PPO s and similar entities are not as clearly sellers of medical services as are HMO. PPO members are merely given financial incentives to patronize preferred providers, but they are free to buy medical services from the provider of their choice. R eimbursement is available (albeit at a reduced rate) even if an unaffiliated provider is selected. ${ }^{144}$

However, the argument that PPOs should not be considered sellers of medical services is not finally persuasive. Presumably, providers accept a PPO's reduced fee schedule and other terms only because they perceive that they will be better off doing so. ${ }^{145}$ That is, they perceive that the PPO business strategy-using financial incentives to induce patients to use selected providers, marketing lists of preferred providers, etc-is likely to generate more patients despite the PPO members' option to patronize unaffiliated providers. The PPO and its providers assume that the PPO incentives will "lock-in" a sufficiently large number of patients to make provider affiliation worthwhile.

If this is the case, PPO s and similar entities occupy substantially the same position as more integrated $\mathrm{MCO}$ s with respect to their ability to influence the quality of the medical services they sell. Their decisions as to network membership, treatment setting, and payment mechanism, will shape the quality of care their members receive. In addition, whether or not they choose to do so, they have the capacity to manage their members' care to assure quality. These rationales for implying a warranty of quality apply with equal force to PPOs and to more integrated MCOs.

D espite the similarities between PPOs and more tightly integrated plans, the prospect that a PPO will pay for services rendered by an independent provider raises the additional question of whether the implied warranty of quality should cover out-of-plan services. A t an intuitive level, the answer would seem to be no. Consumers choosing care from nonparticipating providers do not rely on the plan's judgment in selecting the provider; moreover, the plan has no means of affecting the provider's treatment of the plan member and therefore no mechanism with which to protect itself against liability. On the other hand, relieving the $\mathrm{MCO}$ of responsibility for nonparticipating providers would create some incentive for plans to exclude from their networks providers specializing in the treatment of high-malpractice-risk diseases. ${ }^{146}$ In the case of inte-

144. See generally J ames C. D echene, Preferred Provider Organizations, in MANAGED CARE, supra note 1, at 2-1 to 2-154 (describing PPO s).

145. But see Berenson, supra note 115 , at $175-76$ (noting physician reluctance to drop M CO contracts because of loyalty to patients).

146. See Schleier v. Kaiser Foundation Health Plan, 876 F.2d 174, 178 (D.C. Cir. 1989) ("It might be said that because $\mathrm{K}$ aiser had eliminated cardiology from its coverage, the actions of Sherber, a cardiologist, do not fall within Kaiser's regular business offerings, but we think such an argument circumvents the intention of this final factor- to shield an employer from liability for the actions of an employee who was acting outisde his field of expertise (for example, a doctor who negligently fixes a (car) - and so we consider Sherber's actions to fall within the scope of K aiser's regular business."); see also D ecker v. Saini, N o. 88-361768 NH, 1991 W L 277590 (M ich. Cir. Ct., Oakland C ounty Sept. 17, 1991). The $D$ ecker case included a vicarious liability claim against an H M O based on the negligence of 
grated managed care plans offering a point-of-service option, primary care gatekeepers might even be encouraged to refer particularly high-risk patients to out-of-plan providers to escape liability.

On balance, the better rule is not to imply a warranty of quality with respect to out-of-plan providers to which the patient has self-referred. ${ }^{147}$ Where out-ofplan treatment is the result of a referral by a participating physician, there is good reason to hold the M CO liable notwithstanding the lack of a continuing relationship with the out-of-plan provider: The referring physician can and should be encouraged to exercise some degree of control over the member's care by making a careful referral. A rule that made M COs liable for the malpractice of nonparticipating physicians even when patients self-referred might create strong incentives for health plans to eliminate all coverage for selfreferred services. Because PPOs and point-of-service plans are quite popular among consumers, courts should be wary of inadvertently foreclosing the selfreferral option. In addition, some of the concerns about network design may be alleviated by marketplace forces, accreditation requirements, and regulation.

A final issue concerns the apportionment of liability among multiple M COS in a single chain of distribution. It is not uncommon for HMOS and other payors to contract with physician-hospital organizations, individual practice associations (IPA S), PPO s, and other MCOs in order to establish a network sufficient to serve their patients. A ssuming all the entities in the chain are sellers of medical services, which of them should be liable for a judgment? The best answer is probably all of them. ${ }^{148}$ By definition, each of the entities in the distribution chain is in a contractual relationship. Given this fact and the remarkable variety of health plan structures, courts would be far wiser to hold all sellers of defective services jointly and severally liable, leaving the parties free to negotiate their own indemnity and contribution arrangements as part of their agreements with each other. N ot only would this conclusion protect injured consumers by helping to assure them of compensation, the parties are in a far better position than the courts to determine who is best situated to bear liability risks. In addition, the other entities in the chain would have a strong interest in assuring that the parties they contracted with were financially solvent and could meet their obligations in the event of a large judgment. ${ }^{149}$

a nonparticipating specialist. A lthough the complaint suggested that a participating physician had misrepresented the specialist's status, the court noted that "it would be against public policy to allow $\mathrm{HMOS}$, as a matter of law, to escape liability for their members' treatment by simply referring them outside the HMO plan." Id. at *4. See also Sage et al., supra note 72 , at 24 ("[I]f health plans are spared the cost of malpractice caused by unaffiliated practitioners, they will be less likely to minimize out-of-network utilization by affiliating with the highest quality physicians and to develop systems that provide easy access to emergency services.").

147. Cf. Sage et al., supra note 72, at 24 (arguing that MCOs and out-of-network practitioners should share liability).

148. Cf. RESTATEMENT (THIRD) OF TORTS, supra note $14, \S 1 \mathrm{cmt}$. e.

149. See RICHARD A. POSNER, E CONOMIC A NALYSIS OF LAW 188 (4th ed. 1992); WILliAM M. LANDES \& RICHARD A .POSNER, THE E CONOMIC STRu CTURE OF TORT LAW 205-09 (1987). 


\section{B. Implied Warranty Theory and the Courts}

A Ithough courts have yet to employ an implied warranty of quality theory in a malpractice case involving an $\mathrm{MCO}$, many of the reported decisions that impose liability on M COs are better understood in light of implied warranties than under the doctrines they purport to apply. In Schleier v. Kaiser Foundation $\mathrm{H}$ ealth Plan of the M id-A tlantic States, ${ }^{150}$ for example, the U.S. Court of A ppeals for the D.C. Circuit found that an independent consulting physician was an actual servant of a K aiser H M O. Shedd Smith had been hospitalized by his Kaiser physician after suffering severe chest pain. The Kaiser physician asked Dr. Sherber, "a cardiologist who was an outside consultant and not a Kaiser physician," ${ }^{151}$ to examine M r. Smith. A fter some additional testing, D r. Sherber determined that Smith probably did not have coronary disease and therefore did not restrict his activities. Some six weeks later, M r. Smith died, apparently of coronary artery disease, after mowing his lawn. Smith's personal representative sued $\mathrm{K}$ aiser on account of the failure to diagnose and treat Smith's coronary artery disease.

A pplying the District of Columbia's test, ${ }^{152}$ the court found that a masterservant relationship existed between $K$ aiser and $D r$. Sherber. A ccording to the court, "the most important factor" ${ }^{153}-K$ aiser's power to control Sherber-was met "in that [Sherber] answered to Smith's primary care-taker, a K aiser doctor." ${ }^{154}$ This conclusion is perhaps defensible on the ground that the respondeat superior inquiry asks whether the principal has the right to supervise the agent, not whether it actually did so. ${ }^{155}$ On the other hand, the opinion does not explain in what respects $D r$. Sherber might have been answerable to the unnamed $\mathrm{K}$ aiser physician. Presumably, the reason Dr. Sherber had to be called in was because the Kaiser physician considered himself incompetent to treat Smith adequately. Thus, it seems unlikely that the $K$ aiser physician was reviewing $D r$. Sherber's medical judgment. Nor is there any evidence that Sherber's judgment was controlled directly or indirectly through his relationship with $\mathrm{K}$ aiser.

$V$ iewed in light of the implied warranty theory, however, the case makes perfect sense. Kaiser is a highly-integrated health maintenance organization known for its aggressive and effective management of the cost and quality of the care its patients receive. The K aiser physician, not the patient, selected $D r$. Sherber, and $\mathrm{K}$ aiser paid him, at least in part because $\mathrm{K}$ aiser had no suitable specialist on staff. $K$ aiser owed the plaintiff a duty to stand behind the services it sold.

A similar case, D unn v. Praiss, ${ }^{156}$ involved a consulting physician's failure to

150. 876 F.2d 174 (D.C.Cir. 1989).

151. Id. at 176 .

152. See id. at 177 (quoting L eG rand v. Insurance Co. O f N. A m., 241 A .2d 734, 735 (D.C. 1968)).

153. Id.

154. Id.

155. RESTATEMENT OF A GENCY, supra note 113 , $§ 220$.

156. 606 A.2d 862 (N.J. Super. Ct. A pp. Div. 1992), rev'd on other grounds, 656 A.2d 413 (N.J . 1995). 
diagnose testicular cancer. A s in Schleier, the tortfeasor was not an employee of the decedent's H MO . Instead, he was a urologist employed by an independent medical group that had contracted to provide urological services to the HMO's members on a nonexclusive basis. A ccording to the court, the following facts were sufficient to establish an actual master/servant relationship between the HMO and the urologist: (1) the group was paid on a capitated basis; (2) they were not free to accept or reject individual HMO patients; (3) additional referrals to the group were at the HMO's option; and (4) the urologist examined the decedent on the $\mathrm{HMO}$ 's premises. ${ }^{157}$

A strong argument can be made that the D unn court erred in finding liability on the basis of respondeat superior. While the argument is frequently made that capitation should give rise to an inference of vicarious liability, ${ }_{1}^{158}$ capitation is, in essence, a fixed-price contract between the MCO and its physician. ${ }^{159}$ Such contracts usually indicate an independent contractor relationship because they require the party rendering services to assume business risks, something employees rarely do. ${ }^{160}$ M oreover, capitation seems likely to reduce an M CO 's incentives to supervise contracting physicians, since the MCO no longer bears the risk that the provider will overutilize services.

The second and third factors cited by the Dunn court likewise say nothing about the control the HMO would exert over the medical group's treatment, but arguably relate only to the volume of business the group had undertaken to perform. The fourth factor (examination on $\mathrm{HMO}$ premises) would constitute some evidence of a master/servant relationship in that the HMO provided the place of work and possibly the "tools and instrumentalities" used by the consultant. ${ }^{161}$ Indeed, this fact might lend strong support to a finding of ostensible agency. Nevertheless, evidence for the actual master/servant relationship found in D unn seems slender.

A gain, however, the case is easily understandable under an implied warranty theory. A Ithough the defendant radiologists were not $\mathrm{HMO}$ employees, the HMO selected them and sold their services to the plaintiff. A lthough the factors cited by the court are of marginal relevance to the issue of control, they are extremely relevant to the question of corporate responsibility. The defendant HMO established a payment system it knew created incentives to limit care. It had selected and maintained an ongoing relationship with the radiology group-selling the group's services to the plaintiff on H MO premises as part of

157. Seeid. at 868 .

158. See, e.g. William A. Chittenden, III, M alpractice L iability and M anaged Health Care: H istory and Prognosis, 26 TORT \& INS. L.J. 451, 457 (1991).

159. But see id. at 457 (capitation is "analogous to an employee salary system insofar as the physician's compensation remains the same regardless of the nature or complexity of the medical services rendered.") This statement is true only with respect to gross revenues. The better comparison is between a salary and the provider's net revenues.

160. Cf. LANDES \& POSNER, supra note 149, at 207 ( “ [T] $]$ he independent contractor by definition does not work under the employer's ... direction but rather promises a certain output in exchange for the contract price.").

161. Restatement OF A GENCY, supra note 113, § 220. 
a total package of medical care.

Similar observations can be made about the cases holding M CO s liable on the basis of ostensible agency. In the leading case of Boyd V. A lbert Einstein $M$ edical Center, ${ }^{162}$ a Pennsylvania appellate court reversed a summary judgment in favor of an IPA -model H MO on the vicarious liability issue. D espite the fact that the alleged malpractice was committed by independent physicians, the court found that the facts would support a conclusion that the physicians were the defendant H MO's ostensible agents. Specifically, (1) the H M O "operate[d] on a direct service rather than an indemnity basis," (2) the decedent paid physician fees to the HMO rather than to the treating physician, (3) the decedent selected her physicians from a list provided by the $\mathrm{HMO}$ that included only those who had been screened by the HMO and had agreed to follow its regulations, (4) HMO members could see a specialist only with their primary physician's approval, and (5) when specialty care was approved, HMO members could not choose their treating specialist. ${ }^{163}$

The result in Boyd is more defensible from a doctrinal perspective than those in Schleier and Dunn, if only because the conclusion that an ostensible agency relationship exists is based on a reasonable plaintiff's perceptions rather than on the realities of the MCO-physician relationship. A s noted above, the fact that the plaintiff bought prepaid services from an organization that also restricted the patient's choice as to who would deliver the services adds credibility to the argument that the plaintiff was looking to the plan rather than the provider for medical services. Thus the "direct service" nature of the plan in B oyd, the limitations on plan members' choice of physician, and, particularly, the fact that plan members had no choice at all as to specialist care provide support for the court's conclusion. O $n$ the other hand, there is little indication in the opinion that the plan represented the independent physicians as its servants or that the plaintiff actually relied on their identification with the plan in seeking treatment. A s argued above, it seems doubtful that a listing in a directory of participating providers should amount to the plan's holding out the listed physicians as its agents, especially in a community where providers regularly join multiple networks. In addition, the B oyd court relied extensively on language in the $\mathrm{HMO}$ contract that the injured party may never have read. ${ }^{164}$

The Boyd case is likewise better understood as implying a warranty of quality. M embers of the Boyd H MO could see a specialist only with their primary care physician's approval, and, when specialist treatment was approved, the patient was not permitted to choose the specialist. ${ }^{165}$ The H M O was deliberately structured so that H MO members would see nonspecialists whenever possible. The policy of discouraging self-referral to specialists is certainly defensible; patients often seek out an expensive specialist when the same care could be

162. 547 A .2d 1229 (Pa. Super. Ct. 1988).

163. Id. at 1235.

164. See id. at 1232-34.

165. Seeid. at 1235. 
provided much more cost-effectively through a primary care physician. On the other hand, primary care physicians are by definition generalists. U ndoubtedly, some patients suffer because of limitations on access to specialists. Where an MCO puts structures into place that will foreseeably harm certain patients (even where those structures might be justifiable from a policy perspective), it is no surprise that courts are unwilling to shield them from accountability entirely.

\section{$\mathrm{V}$ \\ CONCLUSION}

The accountability of MCOs has emerged as a crucial issue in connection with the development of a market-based health care system. The implied warranty of quality proposed in this article would represent a significant step in fulfilling the legal system's obligation to ensure that consumers get what they bargain for when they deal with health plans. A Ithough implying a warranty on the part of MCOs is a new idea, it is far from revolutionary. To the contrary, the law's current reluctance to require MCOs to stand behind the services they sell is far more striking than would be the relatively modest extension of existing law called for in this article.

I have proposed the implied warranty of quality as a mechanism for dealing with an important, yet relatively narrow, problem: M CO s' liability for the negligent acts and omissions of affiliated providers. A doption of the implied warranty would produce a number of important beneficial effects-including generating increased quality, efficiency and accountability in the health care system.

The implied warranty theory is also likely to be useful in slowing some of the more destructive trends in managed care liability litigation. In the absence of a straightforward basis for holding M CO s accountable for medical decisions, plaintiffs have attempted to characterize MCO payment mechanisms as inherently wrongful such that their mere use constitutes negligence or even fraud. ${ }^{166}$ Judges and juries, however, are ill-equipped to decide whether such arrangements are reasonable, in large part because legal proceedings focus on the arrangements' effects in the single case before the jury. ${ }^{167}$ In that narrow context, financial incentives that seem entirely defensible in a broader policy framework are easily exploited to paint a picture of a deep-pocketed corporate villain. ${ }^{168}$ If

166. See, e.g., Pulvers v. Kaiser Foundation H ealth Plan, 160 Cal. R ptr. 392 (Ct. A pp. 1979) (ruling that HMO incentive plan does not constitute fraud or breach of warranty because, in the absence of negligent treatment, such plans are consistent with public policy and are not intended to interfere with sound medical judgment); B ush v. D ake, No. 86-25767-NM (M ich. Cir. Ct. A pr. 27, 1989), described in 1 FURROW ET AL., supra note 22, § 8.2c (jury question existed as to whether H M O payment mechanism was proximate cause of physician's negligent failure to order test); G ross v. Prudential Health Care Plan, N o-C) -9474267 (O kla. City Ct. O ct. 1, 1996), reported in 25 H EA LTH LA W DIGEST, 55 n.1 (1997).

167. It has been argued that evidence of the benefits of such arrangements is even inadmissible on the theory that it invites jurors to consider their own financial interests in deciding the case.

168. See Berenson, supra note 115, at 177-78; M ark A. Hall, Rationing $\mathrm{H}$ ealth Care at the B edside, 
such claims prove successful, the risk of large damage awards may force M CO s to discontinue cost-containment mechanisms that appear to have proven effective in controlling health care costs.

Instead of trying to evaluate either the morality or the wisdom of MCO payment mechanisms, courts should focus on the quality of care patients receive. B ecause M COs cannot avoid influencing the quality of care their physicians provide, they should be held responsible when the care they provide does not conform to the malpractice standard. By holding M CO s to an implied warranty of quality, courts can and should short-circuit inquiries into the desirability of contractual arrangements between MCOs and their providers, leaving regulation of managed-care techniques to the market and the political branches of government. ${ }^{169}$

In the space of only a decade or so, the U.S. health care system has been radically transformed. It is no surprise that changes of such magnitude within a relatively short period of time have put stresses on legal frameworks that were established when medicine was practiced the old-fashioned way-by independent practitioners without outside "interference" from hospitals, insurers, and the like. Changes in the health care system demand new forms of accountability. The implied warranty of quality presents an opportunity for courts to adjust to the new realities of health care delivery by drawing on their experience in other settings in which consumers put their safety at risk in the course of transactions with commercial enterprises.

69 N.Y.U.L.REV. 693 (1994).

169. Indeed, ERISA might usefully preempt such claims which, unlike most utilization review decisions, exert significant constraints on health plan administration. 